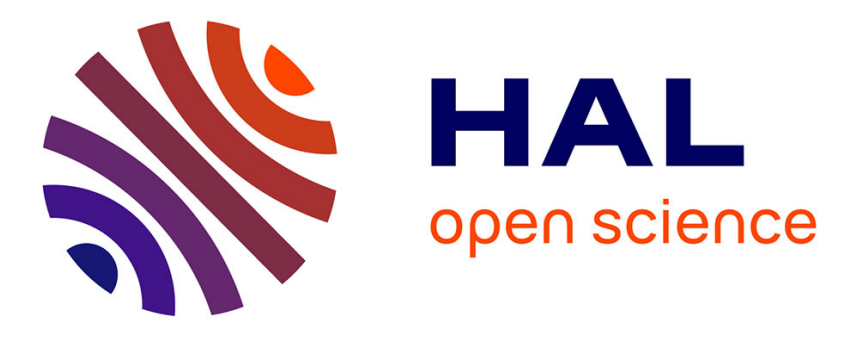

\title{
Exploration of the imidazo[1,2-b]pyridazine scaffold as a protein kinase inhibitor.
}

\author{
Lyamin Z Bendjeddou, Nadège Loaëc, Benoît Villiers, Eric Prina, Gerald F \\ Späth, Hervé Galons, Laurent Meijer, Nassima Oumata
}

\section{- To cite this version:}

Lyamin Z Bendjeddou, Nadège Loaëc, Benoît Villiers, Eric Prina, Gerald F Späth, et al.. Exploration of the imidazo[1,2-b]pyridazine scaffold as a protein kinase inhibitor.. European Journal of Medicinal Chemistry, 2017, 125, pp.696-709. 10.1016/j.ejmech.2016.09.064 • pasteur-01451099

\section{HAL Id: pasteur-01451099}

\section{https://hal-pasteur.archives-ouvertes.fr/pasteur-01451099}

Submitted on 8 Mar 2021

HAL is a multi-disciplinary open access archive for the deposit and dissemination of scientific research documents, whether they are published or not. The documents may come from teaching and research institutions in France or abroad, or from public or private research centers.
L'archive ouverte pluridisciplinaire HAL, est destinée au dépôt et à la diffusion de documents scientifiques de niveau recherche, publiés ou non, émanant des établissements d'enseignement et de recherche français ou étrangers, des laboratoires publics ou privés.

\section{(ㅇ)(1) $\$$}

Distributed under a Creative Commons Attribution - NonCommerciall 4.0 International 
Journal of Medicinal Chemistry

Elsevier Editorial System(tm) for European

Manuscript Draft

Manuscript Number: EJMECH-D-15-01601R1

Title: Exploration of the imidazo[1,2-b]pyridazine scaffold as protein kinase Inhibitors

Article Type: Research Paper

Keywords: kinase inhibitor, imidazo[1,2-b]pyridazine, unicellular parasites, Alzheimer's disease, Down syndrome, alternative splicing, DYRK, CLKS

Corresponding Author: Dr Nassima Oumata, Ph-D

Corresponding Author's Institution: ManRos-Therapeutics

First Author: Nassima Oumata, Ph-D

Order of Authors: Nassima Oumata, Ph-D; Lyamin Bendjeddou; Nadège Loaëc; Benoît Villiers; Eric Prina; Gerald Späth; Hervé Galons; Laurent Meijer

Abstract: Cdc2-like kinases (CLKs) and dual specificity, tyrosine phosphorylation-regulated kinases (DYRKs) are involved in neurodegenerative diseases, such as Alzheimer's disease and Down syndrome. 3,6-disubstituted imidazo[1,2-b]pyridazine derivatives were synthesized to identify new inhibitors of various eukaryotic kinases, including mammalian and protozoan kinases. Among the imidazo[1,2b] pyridazines tested for anti-kinase activity, several molecules were selective for DYRKs and CLKs, with IC50<100 nM. Some compounds showed potent inhibition of Plasmodium falciparum CLK1 (PfCLK1). Compound 20a was found to be the most selective product against CLK1 (IC50 $=82 \mathrm{nM}$ ), CLK4 (IC50 = $44 \mathrm{nM})$, DYRK1A (IC50 = $50 \mathrm{nM})$, and PfCLK1 (IC50 = $32 \mathrm{nM})$. The compounds were also tested against Leishmania amazonensis. Several compounds showed anti-leishmanial activity at rather high (10 $\mu \mathrm{M})$ concentration, but were not toxic at $1 \mu \mathrm{M}$ or $10 \mu \mathrm{M}$, as judged by viability assays carried out using a neuroblastoma cell line. 


\section{C3-optimization}

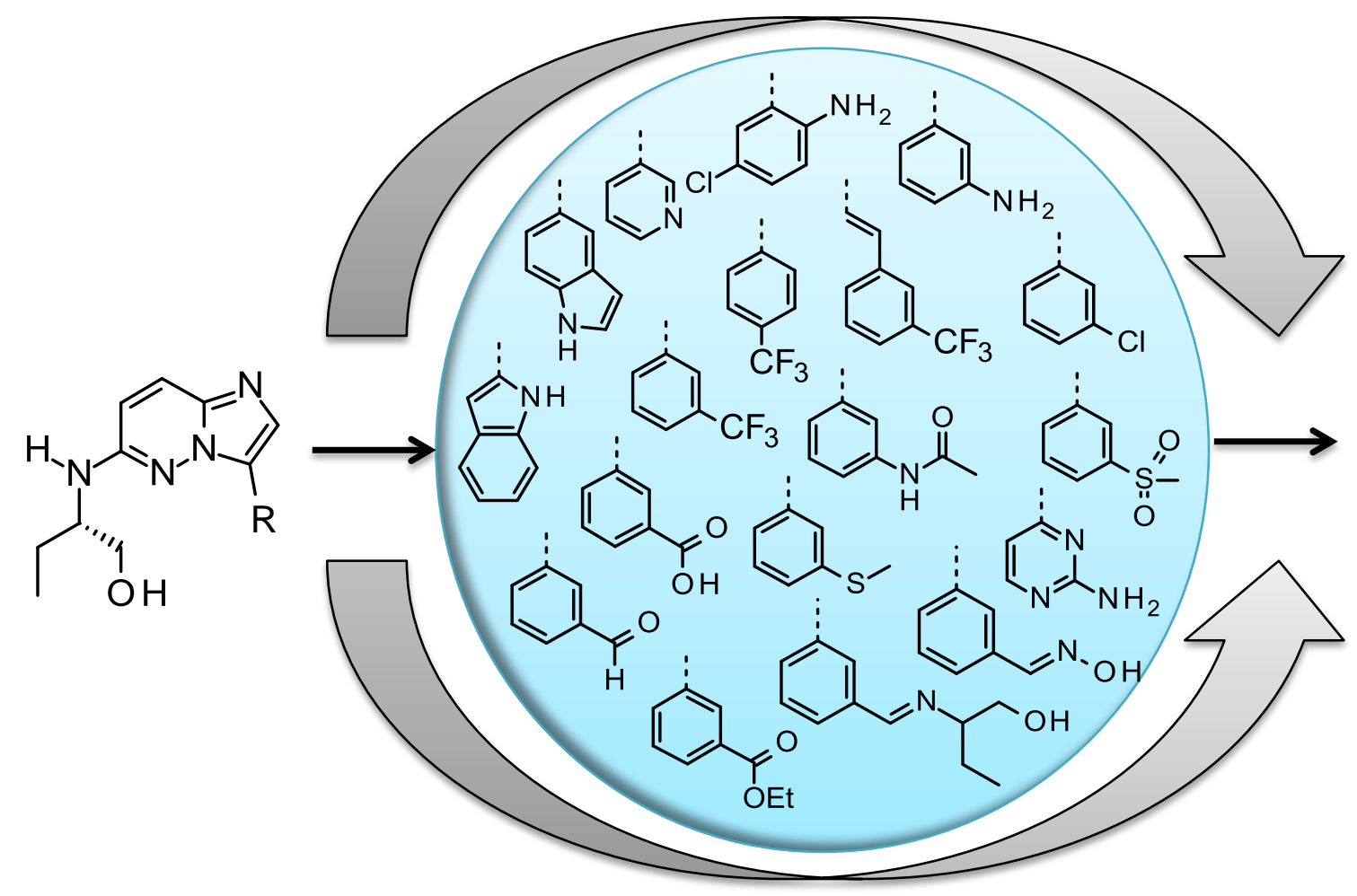

C3-optimization

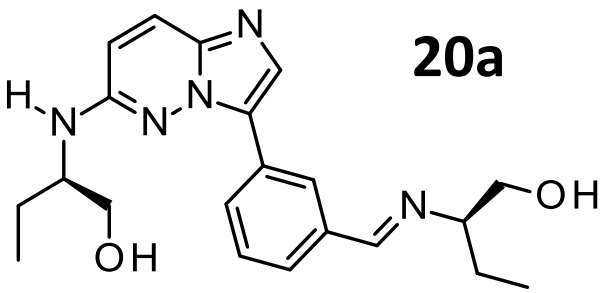
$\mathrm{IC}_{50}: \mathrm{CLK} 1=0.082 \mu \mathrm{M}$ DYRK1A $=0.05 \mu \mathrm{M}$

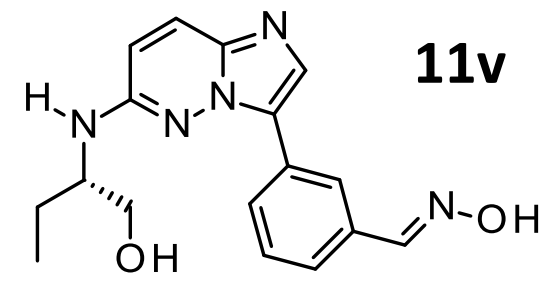

$$
\begin{aligned}
\mathrm{IC}_{50}: \mathrm{CLK1} & =0.023 \mu \mathrm{M} \\
\text { DYRK1A } & =0.025 \mu \mathrm{M}
\end{aligned}
$$


Highlights

- A large variety of imidazo[1,2-b]pyridazines were prepared.

- The prepared compounds were assayed against a panel of mammalian and protozoan kinases.

- Several molecules were found to be selective DYRK and CLK inhibitors.

- Despite their potencies against the kinases studied, the compounds were not cytotoxic. 


\section{Exploration of the imidazo[1,2-b]pyridazine scaffold as protein kinase inhibitors}

Lyamin Z. Bendjeddou ${ }^{\mathrm{a}, \mathrm{b}}$, Nadège Loaëc ${ }^{\mathrm{a}}$, Benoît Villiers ${ }^{\mathrm{a}}$, Eric Prina ${ }^{\mathrm{c}}$, Gerald Späth ${ }^{\mathrm{c}}$, Hervé Galons, ${ }^{\mathrm{b}}$ Laurent Meijer ${ }^{\mathrm{a} *}$ and Nassima Oumata ${ }^{\mathrm{a} * *}$

${ }^{a}$ ManRos Therapeutics, Perharidy Research Center, 29680 Roscoff, Bretagne, France,

${ }^{\mathrm{b}}$ Unité de Technologies Chimiques et Biologiques pour la Santé, Université Paris Descartes

UMR-S 1022 Inserm, 4 avenue de l'Observatoire, 75270 Paris cedex 06, France

c. Institut Pasteur, Unité INSERM U1201, Département des Parasites et Insectes Vecteurs, Unité de Parasitologie Moléculaire et Signalisation, 28 rue du Dr. Roux, 75015 Paris, France

** Correspondence should be addressed to:

Biology: L. Meijer (<meijer@manros-therapeutics.com>)

Chemistry: N. Oumata (<oumata@manros-therapeutics.com>)

Running Title: imidazo[1,2-b]pyridazine kinase inhibitors

Keywords: kinase inhibitor, imidazo[1,2-b]pyridazine, unicellular parasites, Alzheimer's disease, Down syndrome, alternative splicing, DYRK1A, CLKs

\section{Abbreviations:}

AD, Alzheimer's disease; CDKs, cyclin-dependent kinases; CK1, casein kinase 1; CLKs, cdc2-like kinases; CMGC (cyclin-dependent kinase [CDK], mitogen-activated protein kinase [MAPK], glycogen synthase kinase [GSK3], CDC-like kinase [CLK]); CML, chronic myelocytic leukemia; DAD, diode array detector; DEPC, diethyl pyrocarbonate; DMEM, Dulbecco's modified Eagle's medium; DCM, dichloromethane; DMSO, dimethylsulfoxide; DS, Down syndrome; DTT, dithiothreitol; DYRKs, dual-specificity tyrosine phosphorylation 
regulated kinases; FBS, fetal bovine serum; GSH, glutathione; GSK-3, glycogen synthase kinase-3; GST, glutathione-S-transferase; IPTG, isopropyl- $\beta$-D-thiogalactopyranoside; LC, Liquid chromatography; MAP kinases, mitogen-activated protein kinases; NFTs, neurofibrillary tangles; MTS, 3-(4,5-dimethylthiazol-2-yl)-5-(3-carboxymethoxyphenyl)-2(4-sulfophenyl)-2H-tetrazolium; PBS, phosphate-buffered saline; SAR, structure activity relationship; SRp, serine/arginine-rich proteins; TLC, Thin-layer chromatography; TMS, tetramethylsilane.

\section{ABSTRACT}

Cdc2-like kinases (CLKs) and dual specificity, tyrosine phosphorylation-regulated kinases (DYRKs) are involved in neurodegenerative diseases, such as Alzheimer's disease and Down syndrome. 3,6-disubstituted imidazo[1,2-b]pyridazine derivatives were synthesized to identify new inhibitors of various eukaryotic kinases, including mammalian and protozoan kinases. Among the imidazo[1,2-b]pyridazines tested for anti-kinase activity, several molecules were selective for DYRKs and CLKs, with $\mathrm{IC}_{50}<100 \mathrm{nM}$. Some compounds showed potent inhibition of Plasmodium falciparum CLK1 (PfCLK1). Compound 20a was found to be the most selective product against CLK1 $\left(\mathrm{IC}_{50}=82 \mathrm{nM}\right)$, CLK4 $\left(\mathrm{IC}_{50}=44 \mathrm{nM}\right)$, DYRK1A $\left(\mathrm{IC}_{50}\right.$ $=50 \mathrm{nM})$, and PfCLK1 $\left(\mathrm{IC}_{50}=32 \mathrm{nM}\right)$. The compounds were also tested against Leishmania amazonensis. Several compounds showed anti-leishmanial activity at rather high $(10 \mu \mathrm{M})$ concentration, but were not toxic at $1 \mu \mathrm{M}$ or $10 \mu \mathrm{M}$, as judged by viability assays carried out using a neuroblastoma cell line. 


\section{Introduction}

Reversible protein phosphorylation is the most common post-translational modification occurring in many fundamental cellular processes, such as differentiation, division, proliferation, apoptosis, and signal transduction mechanisms. Due to their strong involvement in essentially all physiological processes, dysfunctional phosphorylation can generate many human diseases, such as cancer [1], inflammation, auto-immune and neurodegenerative diseases, and parasite infections. Among the human kinome described by Manning et al. [2] in 2002, the CMGC group, which comprises nine kinase families, has been extremely wellstudied as a group of therapeutic targets. Cdc2-like kinases (CLKs) and dual-specificity tyrosine-phosphorylation-regulated kinases (DYRKs) are families of conserved groups of dual-specificity kinases belonging to the CMGC group, including CDKs (cyclin-dependent kinases), MAP kinases (mitogen-activated protein kinases), GSK-3 (glycogen synthase kinase), and CLKs (Cdc2-like kinases). These two families of kinases auto-phosphorylate at tyrosine residues in their activation loop, but exclusively phosphorylate serine/threonine residues. The CLK family consists of four isoforms: CLK1, CLK2, CLK3, and CLK4. CLKs phosphorylate serine/arginine-rich splicing proteins (SRp), which are implicated in the regulation of alternative splicing [3]. CLK1 is involved in Alzheimer's disease (AD) [4] (splicing of microtubule-associated protein Tau pre-mRNA). The DYRK family comprises five isoforms, DYRK1A, DYRK1B, DYRK2, DYRK3, and DYRK4. The human DYRK1A gene is located on chromosome 21 in the "Down syndrome (DS) critical region" and overexpression of DYRK1A in DS has been associated with neurodegenerative disease [5]. DYRK1A and DYRK1B are also implicated in diverse types of cancers [6,7]. Orthologs of mammalian CLKs and DYRKs are also found in unicellular parasites, such as Leishmania, Trypanosoma, Cryptosporidium, Giardia, Toxoplasma, and Plasmodium. Deregulation or dysfunction of CLKs and DYRKs have been linked to several diseases, which make these kinases attractive potential therapeutic targets.

In the present paper, we describe potent and selective CLK and DYRK inhibitors. We optimized the C-3 position of disubstituted imidazo[1,2-b]pyridazines as CLK and DYRK kinase inhibitors. Our interest in this scaffold is based on the fact that imidazo[1,2b]pyridazines are frequently described as kinase inhibitors. Imidazo[1,2-b]pyridazines have been reported to be inhibitors of CDK2 [8], Pim [9], IKK $\beta$ [10-12], VEGFR2 [13], and Syk [14] (Figure 1). We have identified more than 20 patents issued since 2007 that describe 
imidazo[1,2-b]pyridazines as kinase inhibitors, the most advanced product being Ponatinib [15], which in 2012 was been launched on the market as a BCR-ABL inhibitor in the treatment of chronic myelocytic leukemia (CML). The MRC technology team has described PfPK7 [16] and PfCDPK1 [17,18] inhibitors as being potential antimalarial agents. More recently, diarylimidazo[1,2-b]pyridazines have been identified and evaluated for antiplasmodial activity [19] (Figure 1).

\section{(Figure 1)}

Alzheimer's Disease (AD) is a neurodegenerative disease responsible for the most common form of dementia. It is characterized by extracellular accumulation of amyloid plaque $(A \beta)$ and intracellular deposition of neurofibrillary tangles (NFTs). NFTs mainly result from the aggregation of hyperphosphorylated microtubule-associated Tau protein. Aberrant hyperphosphorylation of Tau induces decreased microtubule binding, causing loss of function and aggregation. CLK1 [4] and DYRK1A [20] have been shown to be involved in neurodegenerative disease, particularly AD. Many CLK and DYRK inhibitors have been described over the last few years, including harmine, TG003 [21] and Indy [22], leucettines [23,24], quinazolines [25-27], KH-CB19 [3], meriolins [28], meridianins [29], imidazopyridazines [30], and most recently, furo- or thieno[3,2-d]pyrimidin-4-amines [31] derived from harmine. We describe the synthesis strategy and biological evaluation of a new series of disubstituted imidazo[1,2-b]pyridazine inhibitors of CLKs and DYRKs. The aim of this work is first to identify new mixed inhibitors of DYRK1A and CLKs, which could be further evaluated in cell and animal AD models. A second objective is to identify inhibitors of orthologous parasitic kinase, which could be useful in the treatment of Leishmania and Plasmodium infections. 


\section{Results and discussion}

\subsection{Chemistry}

A large group of disubstituted imidazo[1,2-b]pyridazines was synthesized, following routes A, B, or C, as depicted in Scheme 1. The synthesis strategy developed provides access to a broad family of disubstituted imidazo[1,2-b]pyridazines. 6-chloroimidazo[1,2-b]pyridazine 1 was obtained by the cyclization of 3-amino-6-chloropyridazine and chloroacetaldehyde at reflux in butanol [8], followed by bromination by $\mathrm{N}$-bromosuccinimide in $\mathrm{CHCl}_{3}$, which yielded 4. A Suzuki cross-coupling reaction at the C-3 position and nucleophilic substitution [32] at C-6 yielded the desired compounds. The aromatic ring can also be introduced by direct arylation on 6-chloroimidazo[1,2-b]pyridazine [33] (route B). An alternative is to introduce the amine at C-6, and to then carry out the Suzuki reaction, or direct arylation. This route $\mathrm{C}$ synthesis allows the introduction of more sensitive groups. (Scheme 1)

Indoles were introduced via route $\mathrm{A}$ at position $\mathrm{C}-3$ by a Suzuki reaction, after $-\mathrm{NH}$ protection by Boc. Nucleophilic substitution at position C-6 was then carried out from $(S)$-2-amino-1butanol in EtOH. Methoxy and sulfonyl groups were obtained by nucleophilic substitution, starting from 5-6. Pyridines were then introduced at the C-3 position. 6-chloro-3-(3pyridyl)imidazo[1,2-b]pyridazines 6e were prepared using both route $\mathrm{A}$ and route $\mathrm{B}$. A $66 \%$ yield was obtained by the Suzuki coupling, compared to $38 \%$ with the $\mathrm{CH}$-arylation reaction. Several protocols have been tested, including nucleophilic substitution for the introduction of the ethyl carbamate. Product $\mathbf{1 4}$ was synthesized using route $\mathrm{C}$, the ethyl carbamate being introduced on 1 by a Buchwald reaction. Bromination of 7a yielded 8a, which led to $\mathbf{1 4}$ after a Suzuki coupling reaction (Scheme 2). The acetanilide derivative 15 was prepared by reacting 6h with 3-aminoacetanilide under Buchwald conditions (Scheme 3). Among the diverse aryl groups introduced on position 3 , compound 11k resulted from the acylation of the aromatic amine 11i.

(Schemes 2, 3, and 4)

Several pyrimidines (11p, 11q, 21f and 21g) were obtained through $\mathrm{CH}$-arylation of 6chloroimidazo[1,2-b]pyridazine 1 (Scheme 5). The sulfones $\mathbf{1 0 d}$ and $\mathbf{2 1 g}$ were converted into the amines 10f, 11r, and 21i (Scheme 6).

(Schemes 5 and 6) 
3-formylphenyl)boronic acid was linked with excellent yield (90\%) on position 3 of $\mathbf{3}$. Imine 20a was the main product obtained from aldehyde $\mathbf{6 m}$ and (R)-2-amino-1-butanol (Scheme 7). An alternative route to imines presented in scheme 8 gave access to acid and imine derivatives in three steps, starting from 6-chloro-3-bromoimidazo[1,2-b]pyridazine. Several oximes were synthesized from an aldehyde in the presence of hydroxylamine and sodium acetate in methanol. We used the same procedure (Scheme 8) for a C-6 position for compounds $\mathbf{1 1 v}$, but we used route A for chlorine (6n) and methoxy (21j) groups. Amide synthesis was the last one we used to complete substituent optimization. The four possible stereoisomers $\mathrm{SS}(\mathbf{1 1 x}), \operatorname{SR}(\mathbf{1 1 y}), \mathrm{RR}(\mathbf{2 0 c})$ and $\mathrm{RS}(\mathbf{2 0 d})$ were prepared (Scheme 9).

\section{Schemes 7, 8, and 9}

\subsection{Evaluation against kinases.}

Our studies originated from testing the biological activity of product A (Figure 2). Among several others, this compound was prepared in the aim of identifying new DYRK and CLK inhibitors. We therefore decided to analyze the structure-activity relationship (SAR) of this class of molecules, particularly by introducing an aromatic ring at the C-3 position. Leucettine L41 was used as a reference product in the evaluation of nov DYRK/CLK inhibitors. In the context of this article, $\mathrm{IC}_{50}$ values obtained with mammalian kinases were in accordance with those reported in a previous paper [24]. $\mathrm{IC}_{50}$ values of leucettine L41 on unicellular parasite DYRK/CLK homologs are shown in table 13, which is added in Supplementary Material.

The indole series revealed a slight inhibition preference for CLKs and DYRKs (Table 1). Two products displaying an $\mathrm{IC}_{50}$ of less than $0.1 \mu \mathrm{M}$, were obtained with substitutions on the indole C-5 position $(0.092 \mu \mathrm{M}$ for $22 \mathrm{~b}$ against CLK4 and $0.098 \mu \mathrm{M}$ for 11a against $L d \mathrm{DYRK} 1 \mathrm{~B})$. With the substituted indole in position C-2 (11b), activity is increased for CLKs/DYRKs, but a bromine atom for compound 11c decreased the activity (Table 1). These results encouraged us to continue optimization by introducing an arylhalide and a trifluromethylphenyl group. Comparing the various C-6 substituents, $(S)$-2-amino-1-butanol 11e $\left(\mathrm{IC}_{50} \mathrm{CLK} 1=0.12 \mu \mathrm{M}\right)$ appeared to be the most active (Table 3). 4trifluoromethylbenzene derivatives 10a, 21c, and 11f synthesized using route B displayed decreased activity and elongation of the ring, further decreasing the activity, but increasing selectivity towards CLK1 and CLK4. (Table 3).

(Table 3) 
The trifluoromethyl group was replaced in the same position by chlorine, the most active compound against CLKs and DYRKs, is substituted by amino alcohol (compound $\mathbf{1 1 h}$, table 4). In order to increase activity and selectivity towards mammalian kinases, the C-3 position was modulated with heterocyclic aromatic and heterocyclic aliphatic amine substitutions.

\section{(Table 4)}

$\mathrm{N}$-(3-aminophenyl)acetamide derivative (15) and 2-piperazin-1-ylethanol derivative (16) displayed good inhibitory activity against CLK1 ( $\mathrm{IC}_{50}$ values of $86 \mathrm{nM}$ and $84 \mathrm{nM}$, respectively). Compound 15 also inhibited PfCLK1 $\left(\mathrm{IC}_{50}=78 \mathrm{nM}\right)$ (Table 4).

Converting the amine (11i) to an acetamide (11k) led to increased activity toward CLKs and DYRKs as well as toward CDK1. Compound 11k inhibited CLK1, CLK2, CLK4, DYRK1A, DYRK1B, DYRK2, and CDK1, with $\mathrm{IC}_{50}$ values of less than $100 \mathrm{nM}$ (Table 5).

Compound 11m was more active than compound 111 on CLK1, CLK2, CLK4, DYRK1A, and DYRK2 (Table 6).

In general, compared to phenyl, the pyrimidines were less active. Pyrimidine appeared not to be the most efficient aryl substitution. Compound 11m (Table 6) was 10-fold more active than 11q the product (Table 7) on CLK1 and DYRK1A (Table 7).

\section{(Tables 5, 6, and 7)}

Compound 11u showed good inhibitory activity against CLK1 (41 nM), CLK4 (41 nM), DYRK1A (79 nM), DYRK1B (53 nM), and DYRK2 (63 nM). Next, chlorine was replaced by fluorine to compare inhibitory activities and to observe the increased reactivity of fluorine over chlorine in nucleophilic substitution. Comparison of compounds $\mathbf{5 b}$ and $\mathbf{6 m}$ (Table 8) revealed decreased inhibitory activity against CDK5, DYRK1A, and DYRK2 for the fluorine derivative, but its inhibitory activity was maintained for CLKs and CK1.

Compound 20a selectively inhibited CLK1, CLK4, and DYRK1A with a low $\mathrm{IC}_{50}$. Among all the compounds tested, 20a seems to be the most potent product; we therefore synthesized its isomer(S)-2-amino-1-butanol via route C. Compound 11s revealed activity, particularly against the CLK and DYRK families, but it also inhibited CDK1 and CDK2 
The S-isomer of amino alcohol $\mathbf{1 1 w}$ was more active than isomer $\mathrm{R}(\mathbf{2 0 a})$ against CLK1 and CLK4, but less active against DYRK1A. Compound 20a also inhibited PfCLK1 (32 nM)m whereas compound $\mathbf{1 1}$ w was 10 -fold less active.

Among all the products described here, compound 11v was the most active against CLK1 (23 $\mathrm{nM}$ ) and CLK4 (25 nM). DYRK1A was inhibited at $33 \mathrm{nM}$ by compound $\mathbf{2 1 \mathbf { j }}$. It is interesting to observe the differences in activity of compounds 11w and 20a (Table 9) All formamides were found to be less active than the imine analogues (Table 10).

(Tables 9 and 10)

\subsection{Cytotoxicity}

Because these products are intended to be used in the treatment of neurodegenerative diseases, it is important that they should not be cytotoxic. All compounds were tested on the SH-SY5Y human neuroblastoma cell-line in a cell-survival assay. The results showed that no compound was cytotoxic at $1 \mu \mathrm{M}$ and $10 \mu \mathrm{M}$.

Since many kinases are involved in proliferation, it may be estimated that the present compounds are not potent inhibitors of other kinases, and may therefore be considered rather selective inhibitors of the kinases under study. (See Supplementary Material, Table 12).

\subsection{Antiparasitic activities}

Finally, in respect to the tests on parasitic kinases, compounds were assayed against $L$. amazonensis. Several compounds were able to reduce parasite proliferation, but at the rather high concentration of $10 \mu \mathrm{M}$ (Table 11).

\section{(Table 11)}

\section{Conclusion}

In conclusion, based on the imidazo[1,2-b]pyridazine scaffold, we have identified and optimized novel CLK1 and DYRK1A inhibitors, and have established a detailed SAR. Investigation of aryl groups at the $\mathrm{C}-3$ position led us to the finding that the imine group was the most active substitutent. A large number of substituents were explored, compound 20a representing the most selective compound against CLK1 and DYRK1A, but also against 
PfCLK1. Since parasite kinases have recently been shown to be potential targets for antimicrobial chemotherapy, we also carried out enzymatic assays with our compounds, using recombinant or purified kinases from various protozoa, including T. brucei, T. cruzi, T. gondii, C. parvum, G. lamblia, L. donovani, and L. major. Furthermore, the compounds were also assessed for anti-leishmanial activity, using a viability assay with Leishmania amazonensis parasites and a phenotypic HCA with intra-macrophagic parasites. Our products showed much less inhibitory activity against Leishmania and Trypanosoma parasite kinases. Alternatively, the oxime derivatives $\mathbf{2 1} \mathbf{j}$ and $\mathbf{1 1 v}$ showed significant inhibitory activity against mammalian CLK1 and DYRK1A. Moreover, cell-survival evaluation showed no cytotoxicity, at least on a neuroblastoma cell line. Finally, several compounds were found to be highly potent against $L$. donovani kinases. However, no correlation was found between this enzymatic inhibitory activity and the effect on Leishmania survival. In fine, the imidazo[1,2b]pyridazine scaffold presents a wide potential for future use in vivo evaluation. The cocrystal structure determination of $\mathbf{1 1 v}$ with several kinases, as previously described in the case of leucettine L41 [24] is to be undertaken.These results will guide future design in this family of imidazo[1,2-b]pyridazines. 


\section{Experimental}

\subsection{Buffers and chemicals}

Buffer A: $10 \mathrm{mM} \mathrm{MgCl}$, 1 mM EGTA (MW 380.4), 1 mM dithiothreitol (DTT) (MW 154.2), $25 \mathrm{mMTris} / \mathrm{HCl}$ (MW 121.1) and $50 \mu \mathrm{g} / \mathrm{mL}$ heparin.

Buffer C: $60 \mathrm{mM}$ B-glycerophosphate, $30 \mathrm{mM}$ p-nitrophenylphosphate, $25 \mathrm{mM}$ MOPS, $5 \mathrm{mM}$ EGTA, $15 \mathrm{mM} \mathrm{MgCl} 2,1 \mathrm{mM}$ DTT and $0.1 \mathrm{mM}$ sodium vanadate.

All chemicals were purchased from Sigma, unless otherwise stated; the protease inhibitor cocktail was obtained from Roche.

\subsection{Protein kinase assays}

Kinase activities were assayed in buffer A or $\mathrm{C}$ at $30{ }^{\circ} \mathrm{C}$ at a final ATP concentration of 15 $\mu \mathrm{mol} / \mathrm{L}$. Blank values were subtracted and activities expressed in percent of maximal activity, i.e., in the absence of inhibitors. Controls were carried out with appropriate DMSO dilutions. The GS-1, CKS, CDK7/9 tide, and RS peptide substrates were obtained from Proteogenix (Oberhausbergen, France).

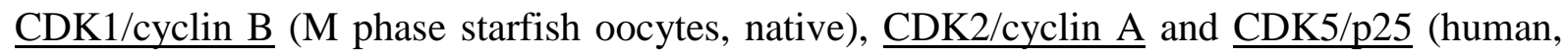
recombinant) were prepared as previously described [33]. Their kinase activity was assayed in buffer A with $1 \mathrm{mg}$ histone $\mathrm{H} 1 / \mathrm{mL}$, in the presence of $15 \mu \mathrm{mol} / \mathrm{L}$ [ $\gamma-33 \mathrm{P}]$ ATP $(3,000$ $\mathrm{Ci} / \mathrm{mmol} ; 10 \mathrm{mCi} / \mathrm{mL}$ ) in a final volume of $30 \mu \mathrm{L}$. After $30 \mathrm{~min}$ incubation at $30{ }^{\circ} \mathrm{C}$, the reaction was stopped by harvesting onto P81 phosphocellulose supernatant (Whatman) using a FilterMate harvester (Packard) and were washed in 1\% phosphoric acid. Scintillation fluid was added and the radioactivity measured in a Packard counter.

CDK9/cyclin $T$ (human, recombinant, expressed in insect cells) was assayed as described for CDK1/cyclin B, but using CDK7/9-tide (YSPTSPSYSPTSPSYSPTSPSKKKK) (8.1 $\mu \mathrm{g}$ /assay) as a substrate.

$\underline{\text { GSK-3 }}$ (porcine brain, native) and PfGSK3 (Plasmodium falciparum, recombinant, expressed in E. coli as glutathione-S-transferase (GST) fusion proteins) was assayed as described for CDK1 with $0.5 \mathrm{mg}$ BSA /mL $+1 \mathrm{mM}$ DTT and using a GSK-3-specific substrate (GS-1: YRRAAVPPSPSLSRHSSPHQSpEDEEE) (pS stands for phosphorylated serine) [33].

$\underline{C K 1 \delta / \varepsilon}$ (porcine brain, native) and LmCK1 (Leishmania major, recombinant, expressed in $E$. coli as HIS fusion proteins) was assayed as described for CDK1, but in buffer C, and using 25 $\mu \mathrm{M}$ CKS peptide (RRKHAAIGpSAYSITA), a CK1-specific substrate [33]. 
DYRKIA, 1B, 2, and 3 (human, recombinant, expressed in E. coli as GST fusion proteins) were purified by affinity chromatography on glutathione-agarose and assayed as described for CDK1/cyclin B with $0.5 \mathrm{mg}$ BSA $/ \mathrm{mL}+1 \mathrm{mM}$ DTT and using Woodtide (KKISGRLSPIMTEQ) (1.5 $\mu \mathrm{g} / \mathrm{assay})$ as a substrate, a residue of transcription factor FKHR.

$\underline{C L K 1}, 2,3$, and 4 (mouse, recombinant, expressed in E. coli as GST fusion proteins) were assayed as described for CDK1/cyclin B with $0.5 \mathrm{mg}$ BSA /mL + $1 \mathrm{mM}$ DTT and RS peptide (GRSRSRSRSRSR) (1 $1 \mu \mathrm{g} /$ assay) as a substrate.

Protozoan DYRKs and CLKs (recombinant, expressed in E. coli) were assayed as described for CDK1/cyclin B with $0.5 \mathrm{mg} \mathrm{BSA} / \mathrm{mL}+1 \mathrm{mM}$ DTT and Woodtide or RS peptide for DYRKs or CLKs isoforms.

\subsection{Production and purification of the parasitic kinases}

The parasitic kinase genes (Table 13) were optimized for expression in E. coli, synthesized and cloned in pGEX-6P-1 (GE Healthcare) with the type II restriction enzymes BamHI and XhoI for glutathione S-transferase (GST) fusion at the N-terminus (GenScript).

The plasmids were transformed into chemically competent $E$. coli BL21(DE3), which were grown overnight at $37^{\circ} \mathrm{C}$ in $2 \mathrm{xYT}$ medium containing $100 \mu \mathrm{g} / \mathrm{mL}$ ampicillin. These cultures were used to inoculate $1 \mathrm{~L}$ volumes of 2 XYT medium (containing $100 \mu \mathrm{g} / \mathrm{mL}$ ampicillin) in 5L flasks. The cultures were allowed to grow at $37{ }^{\circ} \mathrm{C}$ before the temperature was decreased to $18{ }^{\circ} \mathrm{C}$. At an optical density (OD600) of about 1.0, protein expression was induced overnight at $18^{\circ} \mathrm{C}$ with $0.1 \mathrm{mM}$ isopropyl- $\beta$-D-thiogalactopyranoside (IPTG). The bacteria were harvested by centrifugation and frozen at $-20{ }^{\circ} \mathrm{C}$.

Cells were resuspended in lysis buffer (PBS pH 7.4, 1\% NP40, 1 mM DTT, 1 mM EDTA, 1 mM PMSF) in the presence of protease inhibitor cocktail (Roche), and lysozyme was added to $1 \mathrm{mg} / \mathrm{mL}$ and incubated for $1 \mathrm{~h}$ at $4{ }^{\circ} \mathrm{C}$ with gentle agitation. Cells were then sonicated on ice before $\mathrm{MgCl}_{2}(6 \mathrm{mM})$ and benzonase (Novagen, $25 \mathrm{U} / \mathrm{mL}$ ) were added to degrade nucleic acids and decrease sample viscosity. After centrifugation at $4{ }^{\circ} \mathrm{C}$, the soluble fraction was collected and proteins were bound to glutathione (GSH) sepharose 4B beads (GE Healthcare). Beads were washed three times with lysis buffer and once with buffer $\mathrm{C}$ ( $25 \mathrm{mM}$ MOPS pH 7.0, $60 \mathrm{mM} \beta$-glycerophosphate, $15 \mathrm{mM}$ p-nitrophenylphosphate, $15 \mathrm{mM}$ EGTA, $15 \mathrm{mM}$ $\mathrm{MgCl}_{2}, 2 \mathrm{mM}$ DTT, $1 \mathrm{mM}$ sodium vanadate). Proteins were eluted with elution buffer (buffer $\mathrm{C}$ containing $30 \mathrm{mM}$ reduced $\mathrm{GSH}, 15 \%$ glycerol, and $\mathrm{pH}$ adjusted to 8.5).

\subsection{Cell culture conditions; cell survival quantification}


SH-SY5Y cells were grown in DMEM medium from Invitrogen (Cergy-Pontoise, France). All media were supplemented with antibiotics (penicillin-streptomycin) from Lonza and 10\% volume of fetal calf serum from In vitrogen. Cells were cultured at $37{ }^{\circ} \mathrm{C}$ with $5 \% \mathrm{CO}_{2}$. Drug treatments were carried out on exponentially growing cultures at the indicated concentrations. Control experiments were also carried out, using appropriate dilutions of DMSO (maximum $1 \%$ DMSO). Cell Titer $96^{\circledR}$ containing the 3-(4,5-dimethylthiazol-2-yl)-5-(3carboxymethoxyphenyl)-2-(4-sulfophenyl)-2H-tetrazolium (MTS) reagent was purchased from Promega (Madison, WI, USA). Cell viability was determined by measuring the reduction of MTS as described [34].

\subsection{Antileishmanial activity}

\subsubsection{Parasites}

L. amazonensis strain LV79 (MPRO/BR/1972/M1841) expressing the mCherry fluorescent reporter was propagated in Swiss nu/nu mice. Amastigotes were isolated from mouse lesions and used for HCA. Promastigotes were differentiated from lesion-derived amastigotes and grown in M199 medium at $26{ }^{\circ} \mathrm{C}$ for use in dye reduction assay to assess compound toxicity on host cell-free parasites [35].

\subsubsection{Viability assay on host cell-free Leishmania}

An enzymatic assay which incorporates a REDOX indicator (resazurin) that fluoresces in response to cellular metabolic reduction (resofurin) was used to quantify the toxic effect of selected compounds on L. amazonensis promastigotes in axenic conditions. Compounds were tested at three final concentrations $(20,4$, and $0.8 \mu \mathrm{M})$ in quadruplicate.

\section{Supporting information,}

1. Supplementary material 1. Experimental procedures for the synthesis of all compounds. Table 12: cell survival after treatment by prepared compounds. Table 13: Inhibition of parasitic kinases by Leucettine L41. Table 14: Parasitic kinase genes used for the expression of tested kinases.

2. Supplementary material $2 .{ }^{1} \mathrm{H} \mathrm{NMR},{ }^{13} \mathrm{C} \mathrm{NMR}$, IR, and MS spectra. 


\section{Acknowledgements}

This research was supported by grants from the "Fonds Unique Interministériel" (FUI) PHARMASEA, and TRIAD projects (HG, LM), the "Association France-Alzheimer (Finistère)" (LM), the "Fondation Jérôme Lejeune" (LM), ANR grant TRANSLEISH and EEC FP7 European Union $7^{\text {th }}$ Framework Program Knowledge-based Bioeconomy (FP7$\mathrm{KBBE})$ grant BLUEGENICS (LM). 


\section{References}

(1) Zhang, J.; Yang, P. L.; Gray, N. S. Targeting Cancer with Small Molecule Kinase Inhibitors. Nat. Rev. Cancer 2009, 9, 28-39.

(2) Manning, G.; Whyte, D. B.; Martinez, R.; Hunter, T.; Sudarsanam, S. The Protein Kinase Complement of the Human Genome. Science 2002, 298, 1912-1934.

(3) Fedorov, O.; Huber, K.; Eisenreich, A.; Filippakopoulos, P.; King, O.; Bullock, A. N.; Szklarczyk, D.; Jensen, L. J.; Fabbro, D.; Trappe, J.; Rauch, U.; Bracher, F.; Knapp, S. Specific CLK Inhibitors from a Novel Chemotype for Regulation of Alternative Splicing. Chem. Biol.2011, 18, 67-76.

(4) Jain P.; Karthikeyan, C.; Moorthy; N.S.; Waiker, D. K.; Jain, A. K.; Trivedi, P. Human CDC2Like Kinase 1 (CLK1): A Novel Target for Alzheimer's Disease. Curr. Drug Targets 2014, 15, $539-550$.

(5) Becker, W.; Sippl, W. Activation, Regulation, and Inhibition of DYRK1A. FEBS J. 2011, 278, 246-256.

(6) Ionescu, A.; Dufrasne, F.; Gelbcke, M.; Jabin, I.; Kiss, R. DYRK1A Kinase Inhibitors with Emphasis on Cancer. Mini Rev. Med. Chem. 2012, 1315-1329.

(7) Friedman, E. Mirk/dyrk1B Kinase in Ovarian Cancer. Int. J. Mol. Sci. 2013, 14, 5560-5575.

(8) Byth, K. F.; Cooper, N.; Culshaw, J. D.; Heaton, D. W.; Oakes, S. E.; Minshull, C. a; Norman, R. a; Pauptit, R. a; Tucker, J. a; Breed, J.; Pannifer, A.; Rowsell, S.; Stanway, J. J.; Valentine, A. L.; Thomas, A. P. Imidazo[1,2-B]pyridazines: A Potent and Selective Class of CyclinDependent Kinase Inhibitors. Bioorg. Med. Chem. Lett. 2004, 14, 2249-2252.

(9) Bullock, A. N.; Debreczeni, J. E.; Fedorov, O. Y.; Nelson, A.; Marsden, B. D.; Knapp, S. Structural Basis of Inhibitor Specificity of the Human Protooncogene Proviral Insertion Site in Moloney Murine Leukemia Virus (PIM-1) Kinase. J. Med. Chem. 2005, 48, 7604-7614.

(10) Shimizu, H.; Tanaka, S.; Toki, T.; Yasumatsu, I.; Akimoto, T.; Morishita, K.; Yamasaki, T.; Yasukochi, T.; Iimura, S. Discovery of imidazo[1,2-B]pyridazine Derivatives as IKKbeta Inhibitors. Part 1: Hit-to-Lead Study and Structure-Activity Relationship. Bioorg. Med. Chem. Lett.2010, 20, 5113-5118. 
(11) Shimizu, H.; Yasumatsu, I.; Hamada, T.; Yoneda, Y.; Yamasaki, T.; Tanaka, S.; Toki, T.; Yokoyama, M.; Morishita, K.; Iimura, S. Discovery of imidazo[1,2-B]pyridazines as IKK $\beta$ Inhibitors. Part 2: Improvement of Potency in Vitro and in Vivo. Bioorg. Med. Chem. Lett. 2011, 21, 904-908.

(12) Shimizu, H.; Yamasaki, T.; Yoneda, Y.; Muro, F.; Hamada, T.; Yasukochi, T.; Tanaka, S.; Toki, T.; Yokoyama, M.; Morishita, K.; Iimura, S. Discovery of imidazo[1,2-B]pyridazines as IKK $\beta$ Inhibitors. Part 3: Exploration of Effective Compounds in Arthritis Models. Bioorg. Med. Chem. Lett. 2011, 21, 4550-4555.

(13) Matsumoto, S.; Miyamoto, N.; Hirayama, T.; Oki, H.; Okada, K.; Tawada, M.; Iwata, H.; Nakamura, K.; Yamasaki, S.; Miki, H.; Hori, A.; Imamura, S. Structure-Based Design, Synthesis, and Evaluation of imidazo[1,2-b]pyridazine and imidazo[1,2-a]pyridine Derivatives as Novel Dual c-Met and VEGFR2 Kinase Inhibitors. Bioorg. Med. Chem. 2013, 21, 76867698 .

(14) Lucas, M. C.; Goldstein, D. M., Kuglstatter H. C.; Andreas, Liu, W.; Luk, K.C.; Fernando Padilla, F.; Slade, M.; Villaseñor, A.G.; Wanner, J.; Xie, W.; Zhang, X.; Liao, C. Rational Design of Highly Selective Spleen Tyrosine Kinase Inhibitors. J. Med. Chem. 2012, 55, 10414-10423.

(15) Huang, W.-S.; Metcalf, C.; Sundaramoorthi, R.; Wang, Y.; Zou, D.; Thomas, R. M.; Zhu, X.; Cai, L.; Wen, D.; Liu, S.; Romero, J.; Qi, J.; Chen, I.; Banda, G.; Lentini, S. P.; Das, S.; Xu, Q.; Keats, J.; Wang, F.; Wardwell, S.; Ning, Y.; Snodgrass, J. T.; Broudy, M. I.; Russian, K.; Zhou, T.; Commodore, L.; Narasimhan, N. I.; Mohemmad, Q. K.; Iuliucci, J.; Rivera, V. M.; Dalgarno, D. C.; Sawyer, T. K.; Clackson, T.; Shakespeare, W. C. Discovery of 3-[2(imidazo[1,2-B]pyridazin-3-Yl)ethynyl]-4-Methyl-N-\{4-[(4-Methylpiperazin-1-yl)methyl]-3(trifluoromethyl)phenyl benzamide (AP24534), a Potent, Orally Active Pan-Inhibitor of Breakpoint Cluster Region-Abelson (BCR-ABL) Kinase Including Th. J. Med. Chem. 2010, $53,4701-4719$.

(16) Bouloc, N.; Large, J. M.; Smiljanic, E.; Whalley, D.; Ansell, K. H.; Edlin, C. D.; Bryans, J. S. Synthesis and in Vitro Evaluation of Imidazopyridazines as Novel Inhibitors of the Malarial Kinase PfPK7. Bioorg. Med. Chem. Lett. 2008, 18, 5294-5298.

(17) Chapman, T. M.; Osborne, S. a; Bouloc, N.; Large, J. M.; Wallace, C.; Birchall, K.; Ansell, K. H.; Jones, H. M.; Taylor, D.; Clough, B.; Green, J. L.; Holder, A.Substituted 
Imidazopyridazines Are Potent and Selective Inhibitors of Plasmodium Falciparum CalciumDependent Protein Kinase 1 (PfCDPK1). Bioorg. Med. Chem. Lett. 2013, 23, 3064-3069.

(18) Timothy M. Chapman, Simon A. Osborne, Claire Wallace, Kristian Birchall, Nathalie Bouloc, Hayley M. Jones, Keith H. Ansell, Debra L. Taylor, Barbara Clough, Judith L. Green, and A. A. H. Optimization of an Imidazopyridazine Series of Inhibitors of Plasmodium Falciparum Calcium-Dependent Protein Kinase 1 (PfCDPK1). J. Med. Chem. 2014, 57, 3570-3587.

(19) Le Manach, C.; Gonzàlez Cabrera, D.; Douelle, F.; Nchinda, A. T.; Younis, Y.; Taylor, D.; Wiesner, L.; White, K. L.; Ryan, E.; March, C.; Duffy, S.; Avery, V. M.; Waterson, D.; Witty, M. J.; Wittlin, S.; Charman, S. a; Street, L. J.; Chibale, K. Medicinal Chemistry Optimization of Antiplasmodial Imidazopyridazine Hits from High Throughput Screening of a SoftFocus Kinase Library: Part 1..J. Med. Chem., 2014, 57, 2789-2798.

(20) Wegiel, J.; Gong, C.-X.; Hwang, Y.-W. The Role of DYRK1A in Neurodegenerative Diseases. FEBS J. 2011, 278, 236-245.

(21) Muraki, M.; Ohkawara, B.; Hosoya, T.; Onogi, H.; Koizumi, J.; Koizumi, T.; Sumi, K.; Yomoda, J.; Murray, M. V; Kimura, H.; Furuichi, K.; Shibuya, H.; Krainer, A. R.; Suzuki, M.; Hagiwara, M. Manipulation of Alternative Splicing by a Newly Developed Inhibitor of Clks. J. Biol. Chem. 2004, 279, 24246-24254.

(22) Ogawa, Y.; Nonaka, Y.; Goto, T.; Ohnishi, E.; Hiramatsu, T.; Kii, I.; Yoshida, M.; Ikura, T.; Onogi, H.; Shibuya, H.; Hosoya, T.; Ito, N.; Hagiwara, M. Development of a Novel Selective Inhibitor of the Down Syndrome-Related Kinase Dyrk1A. Nat. Commun. 2010, 1, 86.

(23) Debdab, M.; Carreaux, F.; Renault, S.; Soundararajan, M.; Fedorov, O.; Filippakopoulos, P.; Lozach, O.; Babault, L.; Tahtouh, T.; Baratte, B.; Ogawa, Y.; Hagiwara, M.; Eisenreich, A.; Rauch, U.; Knapp, S.; Meijer, L.; Bazureau, J.-P. Leucettines, a Class of Potent Inhibitors of cdc2-like Kinases and Dual Specificity, Tyrosine Phosphorylation Regulated Kinases Derived from the Marine Sponge Leucettamine B: Modulation of Alternative Pre-RNA Splicing. J. Med. Chem. 2011, 54, 4172-4186.

(24) Tahtouh, T.; Elkins, J. M.; Filippakopoulos, P.; Soundararajan, M.; Burgy, G.; Durieu, E.; Cochet, C.; Schmid, R. S.; Lo, D. C.; Delhommel, F.; Oberholzer, A. E.; Pearl, L. H.; Carreaux, F.; Bazureau, J.-P.; Knapp, S.; Meijer, L. Selectivity, Cocrystal Structures, and Neuroprotective Properties of Leucettines, a Family of Protein Kinase Inhibitors Derived from the Marine Sponge Alkaloid Leucettamine B. J. Med. Chem. 2012, 55, 9312-9330. 
(25) Rosenthal, A. S.; Tanega, C.; Shen, M.; Mott, B. T.; Bougie, J. M.; Nguyen, D.-T.; Misteli, T.; Auld, D. S.; Maloney, D. J.; Thomas, C. J. Potent and Selective Small Molecule Inhibitors of Specific Isoforms of Cdc2-like Kinases (Clk) and Dual Specificity Tyrosine-PhosphorylationRegulated Kinases (Dyrk). Bioorg. Med. Chem. Lett. 2011, 21, 3152-3158.

(26) Coombs, T. C.; Tanega, C.; Shen, M.; Wang, J. L.; Auld, D. S.; Gerritz, S. W.; Schoenen, F. J.; Thomas, C. J.; Aubé, J. Small-Molecule Pyrimidine Inhibitors of the cdc2-like (Clk) and Dual Specificity Tyrosine Phosphorylation-Regulated (Dyrk) Kinases: Development of Chemical Probe ML315. Bioorg. Med. Chem. Lett. 2013, 23, 3654-3661.

(27) Pan, Y.; Wang, Y.; Bryant, S. 3D-QSAR Characterization of 6-Arylquinazolin-4-Amines as Cdc2-like Kinase 4 (Clk4) and Dual Specificity Tyrosine-Phosphorylation-Regulated Kinase 1A. J. Chem. Inf. 2013, 4, 938-947.

(28) Echalier, A.; Bettayeb, K.; Ferandin, Y.; Lozach, O.; Clément, M.; Valette, A.; Liger, F.; Marquet, B.; Morris, J. C.; Endicott, J. a; Joseph, B.; Meijer, L. Meriolins (3-(pyrimidin-4-Y1)7-Azaindoles): Synthesis, Kinase Inhibitory Activity, Cellular Effects, and Structure of a CDK2/cyclin A/meriolin Complex. J. Med. Chem.2008, 51, 737-751.

(29) Giraud, F.; Alves, G.; Debiton, E.; Nauton, L.; Théry, V.; Durieu, E.; Ferandin, Y.; Lozach, O.; Meijer, L.; Anizon, F.; Pereira, E.; Moreau, P. Synthesis, Protein Kinase Inhibitory Potencies, and in Vitro Antiproliferative Activities of Meridianin Derivatives. J. Med. Chem.2011, 54, $4474-4489$.

(30) Bullock, A. N.; Das, S.; Debreczeni, J. E.; Rellos, P.; Fedorov, O.; Niesen, F. H.; Guo, K.; Papagrigoriou, E.; Amos, A. L.; Cho, S.; Turk, B. E.; Ghosh, G.; Knapp, S. Kinase Domain Insertions Define Distinct Roles of CLK Kinases in SR Protein Phosphorylation. Structure $2009,17,352-362$.

(31) Loidreau, Y.; Marchand, P.; Dubouilh-Benard, C.; Nourrisson, M.-R.; Duflos, M.; Loaëc, N.; Meijer, L.; Besson, T. Synthesis and Biological Evaluation of N-Aryl-7methoxybenzo[b]furo[3,2-D]pyrimidin-4-Amines and Their N-arylbenzo[b]thieno[3,2D]pyrimidin-4-Amine Analogues as Dual Inhibitors of CLK1 and DYRK1A Kinases. Eur. J. Med. Chem. 2013, 59, 283-295.

(32) Gray. N. S.; Wodicka, L.; Thunnissen, A. M., Norman, T.C.; Kwon, S.; Espinoza, F.H; Morgan, D.O.; Barnes, G.; LeClerc, S.; Meijer, L.; Kim, S.H; Lockhart, D.J; Schulz, P.G. Exploiting Chemical Libraries, Structure, and Genomics in the Search for Kinase Inhibitors. Science 1998, 281, 533-538. 
(33) Oumata, N.; Bettayeb, K.; Ferandin, Y.; Demange, L.; Lopez-Giral, A.; Goddard, M.-L.; Myrianthopoulos, V.; Mikros, E.; Flajolet, M.; Greengard, P.; Meijer, L.; Galons, H. Roscovitine-Derived, Dual-Specificity Inhibitors of Cyclin-Dependent Kinases and Casein Kinases 1. J. Med. Chem. 2008, 51, 5229-5242.

(34) Ribas, J.; Boix J. Cell differentiation caspase inhibition and macromolecular synthesis blockage but not BCL-2 or BCL-XL proteins protect SH-SY5Y cells from apoptosis triggered by two CDK inhibitory drugs. Exp. Cell Res. 2004, 295, 9-24.

(35). Aulner N, Danckaert A, Rouault-Hardoin E, Desrivot J, Helynck O, Commere PH, MunierLehmann H, Späth GF, Shorte SL, Milon G, Prina E. .High content analysis of primary macrophages hosting proliferating Leishmania amastigotes: application to anti-leishmanial drug discovery. PLoS Negl Trop Dis. 2013;7: e2154.

\section{List of tables figure and schemes:}

Table 1. Kinase inhibition values $\left(\mathrm{IC}_{50}\right.$ in $\mu \mathrm{M}$ ) for indole derivatives. $\mathrm{IC}_{50}$ values were estimated from dose-response curves, and are shown in $\mu \mathrm{M}$. $>10$, less than $50 \%$ inhibition at $10 \mu \mathrm{M}$.

Table 2. Kinase inhibition values $\left(\mathrm{IC}_{50}\right.$ in $\left.\mu \mathrm{M}\right)$ for pyridine derivatives. $\mathrm{IC}_{50}$ values were estimated from dose-response curves, and are shown in $\mu \mathrm{M}>10$, less than $50 \%$ inhibition at $10 \mu \mathrm{M}$.

Table 3. Kinase inhibition values $\left(\mathrm{IC}_{50}\right.$ in $\mu \mathrm{M}$ ) for halogens derivatives. $\mathrm{IC}_{50}$ values were estimated from dose-response curves, and are shown in $\mu \mathrm{M}$. $>10$, less than $50 \%$ inhibition at $10 \mu \mathrm{M}$.

Table 4. Kinase inhibition values (IC50 in $\mu \mathrm{M}$ ) for chlorine derivatives. $\mathrm{IC}_{50}$ values were estimated from dose-response curves, and are shown in $\mu \mathrm{M}$. >10, less than 50\% inhibition at $10 \mu \mathrm{M}$. 
Table 5. Kinase inhibition values $\left(\mathrm{IC}_{50}\right.$ in $\mu \mathrm{M}$ ) for amino and acetamido derivatives. $\mathrm{IC}_{50}$ values were estimated from dose-response curves, and are shown in $\mu \mathrm{M}$. $>10$, less than 50\% inhibition at $10 \mu \mathrm{M}$.

Table 6. Kinase inhibition values $\left(\mathrm{IC}_{50}\right.$ in $\mu \mathrm{M}$ ) for compound $11 \mathrm{~m}, \mathbf{1 1 n}$, and $110 . \mathrm{IC}_{50}$ values were estimated from dose-response curves and are shown in $\mu \mathrm{M}$. $>10$, less than $50 \%$ inhibition at $10 \mu \mathrm{M}$.

Table 7. Kinase inhibition values $\left(\mathrm{IC}_{50}\right.$ in $\mu \mathrm{M}$ ) for pyrimidine derivatives. $\mathrm{IC}_{50}$ values were estimated from dose-response curves and are shown in $\mu \mathrm{M}>10$, less than $50 \%$ inhibition at 10 $\mu \mathrm{M}$.

Table 8. Kinase inhibition values $\left(\mathrm{IC}_{50}\right.$ in $\mu \mathrm{M}$ ) for aldehyde, acid, and ester derivatives. $\mathrm{IC}_{50}$ values were estimated from dose-response curves, and are shown in $\mu \mathrm{M}$. >10, less than $50 \%$ inhibition at $10 \mu \mathrm{M}$.

Table 9. Kinase inhibition values $\left(\mathrm{IC}_{50}\right.$ in $\left.\mu \mathrm{M}\right)$ for imine and oxime derivatives.

Table 10. Kinase inhibition values $\left(\mathrm{IC}_{50}\right.$ in $\left.\mu \mathrm{M}\right)$ for amide derivatives. $\mathrm{IC}_{50}$ values were estimated from dose-response curves and are shown in $\mu \mathrm{M}$. $>10$, less than $50 \%$ inhibition at $10 \mu \mathrm{M}$.

Table 11. Anti-leishmanial activity on promastigotes. A miniaturized dye reduction assay (resazurin-based assay) was used to estimate the leishmanicidal activity of each compound. Three compound concentrations $(20,4$, and $0.8 \mu \mathrm{M})$ were tested in quadruplicate for three days on promastigotes. Following subtraction of the mean background fluorescence value from the medium controls, data were expressed as percent of inhibition (PI) as compared to untreated parasite culture wells. The mean +/- standard deviation is shown for every tested compound. PI above $30 \%$ and $75 \%$ are highlighted in bold and underlined, respectively.

Figure 1. The imidazo[1,2-b]pyridazine scaffold: selected kinase inhibitors.

Scheme 1. General synthetic strategy, C3, C6-disubstituted imidazo[1,2-b]pyridazines. Reagent and conditions: (a) i $n \mathrm{BuOH}, 18 \mathrm{~h}$, reflux, ii $\mathrm{H}_{2} \mathrm{O}, \mathrm{NaOH}$; (b) $\mathrm{NBS}, \mathrm{CHCl}_{3}, 8 \mathrm{~h}, 20^{\circ} \mathrm{C}$; (c) boronic acid or ester, $\mathrm{Pd}\left[\mathrm{P}\left(\mathrm{C}_{6} \mathrm{H}_{5}\right)_{3}\right]_{4}, \mathrm{Na}_{2} \mathrm{CO}_{3}(2 \mathrm{M})$, 1,4-dioxane, $100{ }^{\circ} \mathrm{C}$; (d) 2-amino-1-butanol, 160-180 ${ }^{\circ} \mathrm{C}$; (e) $\mathrm{Pd}(\mathrm{OAc})_{2}$, xantphos, tBuOK, $\mathrm{H}_{2} \mathrm{O}, 1,4$-dioxane, $100{ }^{\circ} \mathrm{C}, 48 \mathrm{~h}$; (f) $\mathrm{NaOMe}, \mathrm{MeOH}, 48$ h, reflux; (g)

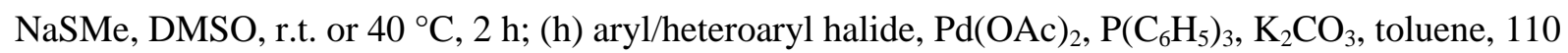
${ }^{\circ} \mathrm{C}$; (i) KF, DMSO/toluene, $170{ }^{\circ} \mathrm{C}, 6 \mathrm{~h}, 30 \%$. 
Scheme 2. Procedure for the synthesis of compound 14. Reagent and conditions: (a) $\operatorname{Pd}(\mathrm{OAc})_{2}$, xantphos, t-BuOK, $\mathrm{H}_{2} \mathrm{O}, 1$,4-dioxane, $100{ }^{\circ} \mathrm{C}, 24 \mathrm{~h}, 27 \%$; (b) NBS, $\mathrm{CHCl}_{3}, 20{ }^{\circ} \mathrm{C}, 4 \mathrm{~h}, 100 \%$; (c) 3chlorophenylboronic pinacol ester, $\mathrm{Pd}\left[\mathrm{P}(\mathrm{Ph})_{3}\right]_{4}, \mathrm{Na}_{2} \mathrm{CO}_{3}(2 \mathrm{M}), 1,4$-dioxane, $100{ }^{\circ} \mathrm{C}, 6 \mathrm{~h}, 5 \%$.

Scheme 3. Procedure for the synthesis of compound 15. Reagents and conditions: (a) $\operatorname{Pd}(\mathrm{OAc})_{2}$, xantphos, $t$-BuOK, $\mathrm{H}_{2} \mathrm{O}, 1,4$-dioxane, $100{ }^{\circ} \mathrm{C}, 24 \mathrm{~h}, 30 \%$.

Scheme 4. Procedure for the synthesis of acetamides 111 and 18. Reagents and conditions: (a) acetic anhydride, DMAP, Et 3 N, DCM, $20{ }^{\circ} \mathrm{C}, 2$ h, 79\%; (b) (S)-2-amino-1-butanol, $160{ }^{\circ} \mathrm{C}, 7 \mathrm{~h}, 7 \%$; (b') (S)2-amino-1-butanol, $180{ }^{\circ} \mathrm{C}, 7$ h, 26\%; (a') acetic anhydride, DMAP, $\mathrm{Et}_{3} \mathrm{~N}$, DCM, r.t., 2 h, $57 \%$.

Scheme 5. Procedure for the synthesis of pyrimidine derivatives. Reagents and conditions: (a) TMSBr, $\mathrm{CH}_{3} \mathrm{CN}, 40{ }^{\circ} \mathrm{C}, 27 \mathrm{~h}, 98 \%$; (b) 6-chloro-imidazo[1,2-b]pyridazine, $\mathrm{Pd}(\mathrm{OAc})_{2}, \mathrm{PPh}_{3}, \mathrm{~K}_{2} \mathrm{CO}_{3}$, toluene, 2 days, $110{ }^{\circ} \mathrm{C}, 38 \%$; (c) mCPBA, DCM, r.t.; (d) $\mathrm{MeONa}, \mathrm{MeOH}, 6 \mathrm{~h}, 80^{\circ} \mathrm{C}$; (e) (S)-2amino-1-butanol, $170{ }^{\circ} \mathrm{C}, 4 \mathrm{~h}$.

Scheme 6. Procedure for the synthesis of pyrimidine derivatives. Reagents and conditions: (g) 1,4dioxane, 8 h, reflux; (h) TFA, DCM, $20{ }^{\circ} \mathrm{C}$; (i) (S)-2-amino-1-butanol, 6 h, $160{ }^{\circ} \mathrm{C}$.

Scheme 7. Procedure for the synthesis of imines. Reagents and conditions: (a) KF, DMSO/toluene, 8 h, $180^{\circ} \mathrm{C}, 46 \%$; (b) $\mathrm{NBS}, \mathrm{CHCl}_{3}, 6$ h, r.t., 93\%; (c) 3-formylphenylboronic acid, $\mathrm{Pd}\left[\mathrm{P}\left(\mathrm{C}_{6} \mathrm{H}_{5}\right)_{3}\right]_{4}$, $\mathrm{Na}_{2} \mathrm{CO}_{3}(2 \mathrm{M}), 1,4$-dioxane, $100{ }^{\circ} \mathrm{C}, 6 \mathrm{~h}, 63 \%$; (d) (R)-2-amino-1-butanol, $135^{\circ} \mathrm{C}, 2 \mathrm{~h}$.

Scheme 8. Procedure for the synthesis of acid and ethyl ester derivative. Reagents and conditions : (a) (S)-2-amino-1-butanol, $8 \mathrm{~h}, 180{ }^{\circ} \mathrm{C}$, 69\%; (c) ethyl 3-bromobenzoate, $\mathrm{Pd}(\mathrm{OAc})_{2}, \mathrm{P}\left(\mathrm{C}_{6} \mathrm{H}_{5}\right)_{3}, \mathrm{~K}_{2} \mathrm{CO}_{3}$, toluene, $8 \mathrm{~h}, 110^{\circ} \mathrm{C}, 10 \%$; (c) i: $\mathrm{NaOH}(1 \mathrm{~N}), \mathrm{THF} / \mathrm{EtOH}$, ii: $\mathrm{HCl}(1 \mathrm{~N}), \mathrm{H}_{2} \mathrm{O}, 28 \%$; (d) 3-

formylphenylboronic acid, $\mathrm{Pd}\left[\mathrm{P}\left(\mathrm{C}_{6} \mathrm{H}_{5}\right)_{3}\right]_{4}, \mathrm{Na}_{2} \mathrm{CO}_{3}(2 \mathrm{M})$, 1,4-dioxane, $100{ }^{\circ} \mathrm{C}, 12 \mathrm{~h}$. (e) (S)-2-amino1-butanol, 3 days, 20 to $60^{\circ} \mathrm{C}$.

Scheme 9: Procedure of the synthesis of amide. Reagents and conditions: (a) (S or R)-2amino-1-butanol, DCC/HOBt, $\mathrm{Et}_{3} \mathrm{~N}$, THF/DCM, $20^{\circ} \mathrm{C}, 24 \mathrm{~h}$; (b) (S or R)-2-amino-1-butanol, $180{ }^{\circ} \mathrm{C}, 12 \mathrm{~h}$. 
Table 1. Kinase inhibition values : $\mathrm{IC}_{50}{ }^{\mathrm{a}}$ in $\mu \mathrm{M}$ for indole derivatives

\begin{tabular}{|c|c|c|c|c|c|c|}
\hline Compd & $6 a$ & 21a & $22 b$ & $11 \mathrm{a}$ & $11 b$ & $11 \mathrm{c}$ \\
\hline CDK1 & 4.1 & 4.3 & 2.7 & 2.7 & 1.8 & 1.7 \\
\hline CDK2 & 5.9 & $>10$ & 9.1 & 41 & 4.1 & 9.1 \\
\hline CDK5 & 6.7 & 5.1 & 4.2 & 3.1 & 1.2 & 8.3 \\
\hline CDK9 & 5 & 3.1 & 2 & 2.8 & 1.1 & 0.22 \\
\hline CK1 & 2.8 & 1.2 & 1.2 & 5 & 2.1 & 10 \\
\hline CLK1 & 0.13 & 0.22 & 0.13 & 0.27 & 0.11 & 1.2 \\
\hline CLK2 & 1 & 0.71 & 0.22 & 2.2 & 0.38 & 1.9 \\
\hline CLK3 & 5.2 & 3.1 & 5.8 & 21 & 2.4 & 10 \\
\hline CLK4 & 0.12 & 0.18 & 0.092 & 0.21 & 0.12 & 1 \\
\hline DYRK1A & 2.4 & 0.47 & 0.58 & 0.35 & 0.34 & 0.71 \\
\hline DYRK1B & 1.2 & 1.2 & 1.4 & 0.96 & 0.22 & 2.1 \\
\hline DYRK2 & 0.61 & 0.32 & 0.44 & 0.38 & 0.21 & 1.2 \\
\hline DYRK3 & 4.7 & 0.91 & 1.2 & 1.8 & 0.12 & 0.61 \\
\hline GSK-3 & 5.6 & 4.3 & $>10$ & 2.7 & 2.3 & 10 \\
\hline LdDYRK1B & 1.8 & 1.2 & 3.1 & 0.098 & 0.15 & 0.13 \\
\hline$L d$ DYRK3 & $>10$ & 9.2 & $>10$ & $>10$ & 10 & 10 \\
\hline LdDYRK4 & $>10$ & $>10$ & $>10$ & $>10$ & 10 & 10 \\
\hline TbCLK1 & $>10$ & $>10$ & $>10$ & $>10$ & 10 & 10 \\
\hline Tc CLK1 & $>10$ & $>10$ & $>10$ & $>10$ & 10 & 10 \\
\hline CpCLK1 & 1.2 & 2.7 & 4.2 & 3.1 & 10 & 10 \\
\hline GlCLK & 5.9 & 5.2 & 8.1 & 1.1 & 2.1 & 2.9 \\
\hline$T g C L K$ & 2.8 & 4.1 & 4.1 & 4.1 & 10 & 10 \\
\hline LmDYRK2 & 4 & 5 & $>10$ & 3.9 & 4.1 & 10 \\
\hline $\operatorname{LmCLK}$ & $>10$ & $>10$ & $>10$ & 10 & 10 & 10 \\
\hline PfCLK1 & 1.6 & 1.3 & 0.9 & 2.2 & 2.2 & 10 \\
\hline
\end{tabular}

${ }^{\mathrm{a}} \mathrm{IC}_{50}$ values were estimated from dose-response curves and are shown in $\mu \mathrm{M} .>10$, less than $50 \%$ inhibition at $10 \mu \mathrm{M}$. 
Table 2. Kinase inhibition values: $\mathrm{IC}_{50}{ }^{\mathrm{a}}$ in $\mu \mathrm{M}$ for pyridine derivatives.
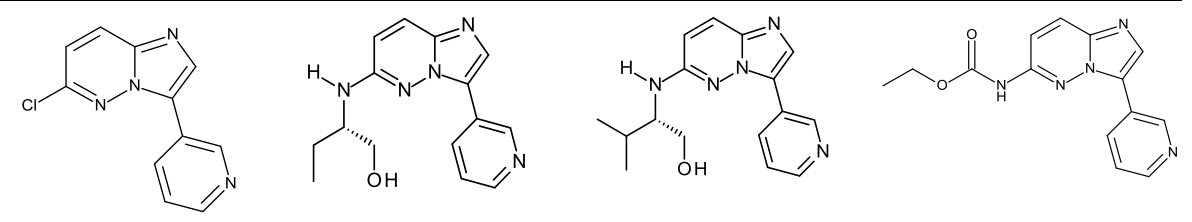

6e

11d

12

13

Compd

\begin{tabular}{|c|c|c|c|c|}
\hline CDK1 & $>10$ & 3 & 2.3 & $>10$ \\
\hline CDK2 & 71 & 3.4 & 3.2 & $>10$ \\
\hline CDK5 & 4.7 & 1.7 & 1.4 & $>10$ \\
\hline CDK9 & $>10$ & 2.1 & 1.2 & $>10$ \\
\hline CK1 & 4.1 & 5.1 & 1.2 & $>10$ \\
\hline CLK1 & 0.89 & 0.19 & 0.18 & $>10$ \\
\hline CLK2 & 4.1 & 0.71 & 0.59 & $>10$ \\
\hline CLK3 & 42 & 3.9 & 3.3 & $>10$ \\
\hline CLK4 & 0.4 & 0.059 & 0.09 & $>10$ \\
\hline DYRK1A & 13 & 0.87 & 0.39 & $>10$ \\
\hline DYRK1B & 20 & 0.51 & 0.13 & $>10$ \\
\hline DYRK2 & 11 & 0.6 & 0.19 & $>10$ \\
\hline DYRK3 & 16 & 0.95 & 0.32 & $>10$ \\
\hline GSK-3 & 51 & 3 & 5.1 & $>10$ \\
\hline$L d \mathrm{DYRK1B}$ & $>10$ & 0.69 & 0.39 & $>10$ \\
\hline$L d \mathrm{DYRK3}$ & $>10$ & $>10$ & $>10$ & $>10$ \\
\hline$L d$ DYRK4 & $>10$ & $>10$ & $>10$ & $>10$ \\
\hline TbCLK1 & $>10$ & $>10$ & $>10$ & $>10$ \\
\hline TcCLK1 & $>10$ & $>10$ & $>10$ & $>10$ \\
\hline CpCLK1 & $>10$ & 2.2 & 3.8 & $>10$ \\
\hline
\end{tabular}




\begin{tabular}{ccccc}
\hline $\boldsymbol{G l C L K}$ & $>10$ & 0.71 & 4.2 & $>10$ \\
\hline $\boldsymbol{T g C L K}$ & $>10$ & 4.9 & 5.2 & $>10$ \\
\hline $\boldsymbol{L m D Y R K 2}$ & $>10$ & 5.7 & 6.5 & $>10$ \\
\hline $\boldsymbol{L m C L K}$ & $>10$ & $>10$ & $>10$ & $>10$ \\
\hline $\boldsymbol{P f C L K 1}$ & $>10$ & 3 & 1.3 & $>10$ \\
\hline
\end{tabular}

${ }^{\mathrm{a}} \mathrm{IC}_{50}$ values were estimated from dose-response curves and are shown in $\mu \mathrm{M}>10$, less than $50 \%$ inhibition at $10 \mu \mathrm{M}$. 
Table 3. Kinase inhibition values: $\mathrm{IC}_{50}{ }^{\mathrm{a}}$ in $\mu \mathrm{M}$ for halogens derivatives
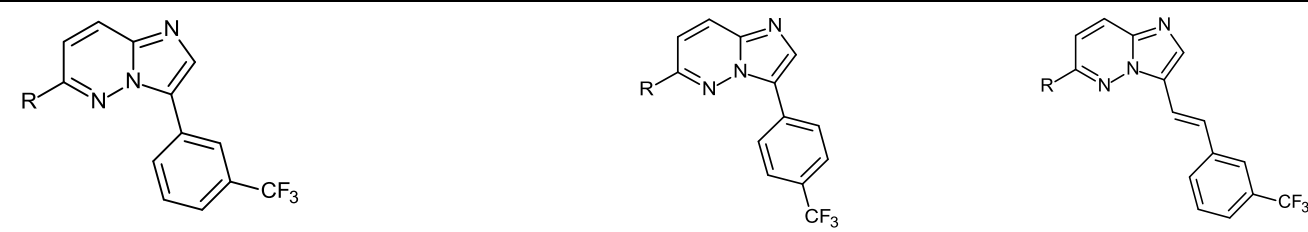

\begin{tabular}{|c|c|c|c|c|c|c|c|c|c|c|c|}
\hline $\mathbf{R}$ & $\mathrm{Cl}$ & $\mathrm{F}$ & $\mathrm{OMe}$ & $\mathrm{SMe}$ & O & $\mathrm{Cl}$ & $\mathrm{OMe}$ & & $\mathrm{Cl}$ & $\mathrm{OMe}$ & Or \\
\hline Compd & $6 f$ & $5 a$ & $21 b$ & $22 c$ & 11e & $10 a$ & $21 c$ & 11f & $6 \mathrm{~g}$ & 21d & $11 \mathrm{~g}$ \\
\hline CDK1 & 7.5 & $>10$ & 3.3 & 1.4 & 1.3 & $>10$ & 5.1 & 1.7 & $>10$ & $>10$ & $>10$ \\
\hline CDK2 & 45 & $>10$ & 12 & 7.8 & 82 & $>10$ & 5.1 & 5.3 & $>10$ & $>10$ & $>10$ \\
\hline CDK5 & 4.7 & $>10$ & 18 & 0.75 & 50 & $>10$ & $>10$ & 7.1 & $>10$ & $>10$ & $>10$ \\
\hline CDK9 & $>10$ & $>10$ & 8.1 & 4 & 1.7 & $>10$ & $>10$ & 7.5 & $>10$ & $>10$ & 3.7 \\
\hline CK1 & 8.1 & $>10$ & 10 & 5.9 & $>10$ & 3.6 & 2.4 & 3.8 & 5.1 & $>10$ & $>10$ \\
\hline CLK1 & 0.58 & 2.8 & 0.79 & 0.33 & 0.12 & 2.7 & 1.1 & 0.18 & 0.59 & 0.51 & 0.79 \\
\hline CLK2 & 2.8 & 6.3 & 1.5 & 0.54 & 0.38 & 5.9 & 1.8 & 1.4 & 1.3 & 0.89 & 9.1 \\
\hline CLK3 & $>100$ & $>10$ & 12 & 12 & 39 & 8.8 & $>10$ & $>10$ & $>10$ & $>10$ & $>10$ \\
\hline CLK4 & 0.57 & 1.5 & 0.61 & 0.23 & 0.17 & 2.1 & 0.98 & 0.18 & 0.32 & 0.22 & 0.41 \\
\hline DYRK1A & 7.8 & 4.2 & 1.3 & 1 & 0.22 & 7.3 & 2.8 & 1.1 & 8.9 & $>10$ & $>10$ \\
\hline DYRK1B & 0.82 & $>10$ & 3.4 & 1.7 & 0.19 & $>10$ & 3.6 & 1.1 & 7.1 & $>10$ & $>10$ \\
\hline DYRK2 & 0.48 & 6.3 & 1.2 & 1.8 & 0.18 & 8.6 & 2.5 & 0.78 & 7.1 & $>10$ & $>10$ \\
\hline DYRK3 & $>10$ & $>10$ & 5.3 & 3 & $>100$ & $>10$ & 4.9 & 2.1 & $>10$ & $>10$ & $>10$ \\
\hline GSK-3 & $>100$ & $>10$ & 22 & 12 & 91 & $>10$ & $>10$ & $>10$ & $>10$ & $>10$ & $>10$ \\
\hline LdDYRK1B & 2.1 & $>10$ & 2.2 & 4.1 & 1.2 & $>10$ & 3.1 & 0.42 & $>10$ & $>10$ & $>10$ \\
\hline$L d \mathrm{DYRK3}$ & $>10$ & $>10$ & $>10$ & $>10$ & $>10$ & $>10$ & $>10$ & $>10$ & $>10$ & 6.4 & 2.2 \\
\hline$L d D Y R K 4$ & $>10$ & $>10$ & $>10$ & $>10$ & $>10$ & $>10$ & $>10$ & $>10$ & $>10$ & $>10$ & $>10$ \\
\hline TbCLK1 & $>10$ & $>10$ & $>10$ & $>10$ & $>10$ & $>10$ & $>10$ & $>10$ & $>10$ & $>10$ & $>10$ \\
\hline
\end{tabular}




\begin{tabular}{|c|c|c|c|c|c|c|c|c|c|c|c|}
\hline TcCLK1 & $>10$ & $>10$ & $>10$ & $>10$ & $>10$ & $>10$ & $>10$ & $>10$ & $>10$ & $>10$ & $>10$ \\
\hline CpCLK1 & $>10$ & $>10$ & $>10$ & 3 & 2.3 & $>10$ & $>10$ & $>10$ & $>10$ & $>10$ & $>10$ \\
\hline GlCLK & $>10$ & $>10$ & $>10$ & $>10$ & $>10$ & $>10$ & $>10$ & 3.9 & $>10$ & $>10$ & $>10$ \\
\hline TgCLK & $>10$ & $>10$ & $>10$ & 2 & $>10$ & $>10$ & $>10$ & $>10$ & $>10$ & $>10$ & $>10$ \\
\hline LmDYRK2 & $>10$ & $>10$ & $>10$ & 7.1 & $>10$ & $>10$ & 7.8 & $>10$ & $>10$ & $>10$ & $>10$ \\
\hline LmCLK & $>10$ & $>10$ & $>10$ & $>10$ & $>10$ & $>10$ & $>10$ & $>10$ & $>10$ & $>10$ & $>10$ \\
\hline PfCLK1 & 8 & $>10$ & $>10$ & 2.9 & 8.6 & 4.5 & 4.5 & 3.9 & 7 & $>10$ & $>10$ \\
\hline
\end{tabular}

${ }^{\mathrm{a}} \mathrm{IC}_{50}$ values were estimated from dose-response curves and are shown in $\mu \mathrm{M}$. >10, less than $50 \%$ inhibition at $10 \mu \mathrm{M}$. 
Table 4. Kinase inhibition values: $\mathrm{IC}_{50}{ }^{\mathrm{a}}$ in $\mu \mathrm{M}$ for chlorine derivatives.

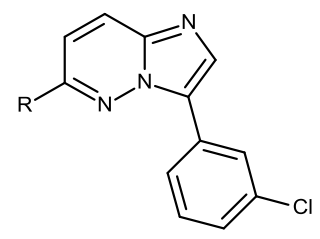

R<smiles>CCC(CO)[NH+](C)C</smiles><smiles>CCOC([NH2+])=O</smiles><smiles>CNc1cccc(NC(C)=O)c1</smiles><smiles>OCCN1CC[N]CC1</smiles><smiles>C[NH2+]CC1CCCCC1N1CCCCC1</smiles>

\begin{tabular}{|c|c|c|c|c|c|c|}
\hline Compd & $6 \mathbf{h}$ & $11 \mathrm{~h}$ & 14 & 15 & 16 & 17 \\
\hline CDK1 & 6.7 & 1.1 & $>10$ & 0.89 & 8.2 & $>10$ \\
\hline CDK2 & 10 & $>10$ & $>10$ & 4 & $>10$ & $>10$ \\
\hline CDK5 & 6.8 & 0.61 & $>10$ & 0.39 & $>10$ & $>10$ \\
\hline CDK9 & 4.8 & 0.22 & $>10$ & 2.1 & 1 & 0.62 \\
\hline CK1 & 6.7 & 1.1 & $>10$ & $>10$ & 0.9 & 0.4 \\
\hline CLK1 & 0.23 & 0.048 & 0.63 & 0.086 & 0.084 & 1.8 \\
\hline CLK2 & 2.1 & 0.22 & 1.2 & 0.13 & 1.2 & 1.9 \\
\hline CLK3 & $>10$ & $>10$ & $>10$ & 1.8 & $>10$ & $>10$ \\
\hline CLK4 & 0.15 & 0.043 & 0.52 & 0.1 & 0.51 & 0.8 \\
\hline DYRK1A & 1.4 & 0.075 & 0.42 & 0.11 & 0.51 & 2.8 \\
\hline DYRK1B & 1.7 & 0.051 & 1.1 & 0.18 & 0.52 & 3.6 \\
\hline DYRK2 & 1.3 & 0.05 & 1.6 & 0.11 & 0.44 & 3.2 \\
\hline DYRK3 & 3 & 0.081 & 7.1 & 5.3 & 0.43 & 1.1 \\
\hline GSK-3 & $>10$ & $>10$ & $>10$ & $>10$ & $>10$ & $>10$ \\
\hline LdDYRK1B & 6.2 & 0.19 & $>10$ & 0.59 & 1.8 & $>10$ \\
\hline$L d D Y R K 3$ & $>10$ & $>10$ & $>10$ & $>10$ & $>10$ & $>10$ \\
\hline LdDYRK4 & $>10$ & $>10$ & $>10$ & $>10$ & $>10$ & $>10$ \\
\hline TbCLK1 & $>10$ & $>10$ & $>10$ & $>10$ & $>10$ & $>10$ \\
\hline TcCLK1 & $>10$ & $>10$ & $>10$ & $>10$ & $>10$ & $>10$ \\
\hline CpCLK1 & 5.1 & 6.1 & $>10$ & $>10$ & $>10$ & $>10$ \\
\hline
\end{tabular}




\begin{tabular}{ccccccc}
\hline $\boldsymbol{G l C L K}$ & $>10$ & $>10$ & $>10$ & $>10$ & $>10$ & $>10$ \\
\hline $\boldsymbol{T g C L K}$ & 7.1 & $>10$ & $>10$ & $>10$ & $>10$ & $>10$ \\
\hline $\boldsymbol{L}$ DYRK2 & 8.3 & $>10$ & $>10$ & 0.5 & 8.9 & $>10$ \\
\hline $\boldsymbol{L m C L K}$ & $>10$ & $>10$ & $>10$ & $>10$ & $>10$ & 4.1 \\
\hline $\boldsymbol{P f C L K 1}$ & 3.4 & 1.2 & $>10$ & 0.078 & 1.2 &
\end{tabular}

${ }^{\mathrm{a}} \mathrm{IC}_{50}$ values were estimated from dose-response curves and are shown in $\mu \mathrm{M}$. $>10$, less than $50 \%$ inhibition at $10 \mu \mathrm{M}$. 

Table 5. Kinase inhibition values $\mathrm{IC}_{50}{ }^{\mathrm{a}}$ in $\mu \mathrm{M}$ ) for amino and acetamido derivatives.
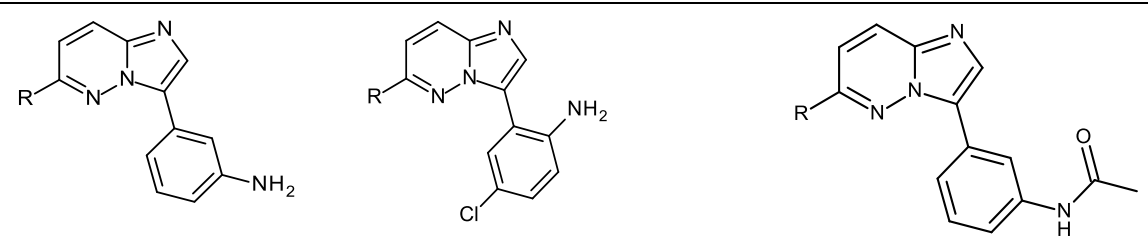

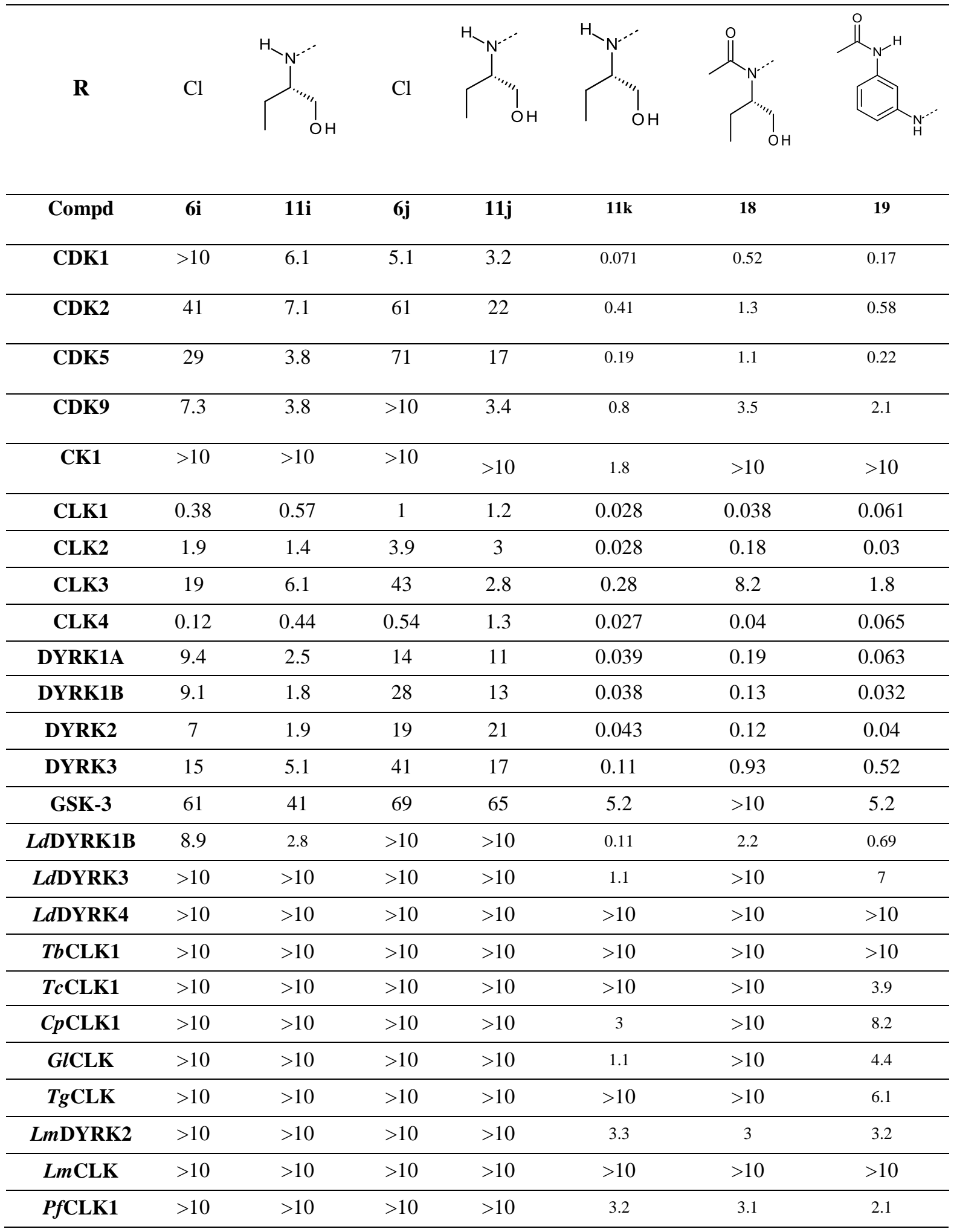


${ }^{\mathrm{a}} \mathrm{IC}_{50}$ values were estimated from dose-response curves and are shown in $\mu \mathrm{M}$. $>10$, less than $50 \%$ inhibition at $10 \mu \mathrm{M}$. 
Table 6. Kinase inhibition values $\mathrm{IC}_{50}{ }^{\mathrm{a}}$ in $\mu \mathrm{M}$ for compound $\mathbf{1 1 m}, \mathbf{1 1 n}$ and $\mathbf{1 1 0}$.

\begin{tabular}{|c|c|c|c|}
\hline Compd & 111 & $11 \mathrm{~m}$ & $11 n$ \\
\hline CDK1 & 0.51 & 0.27 & 0.8 \\
\hline CDK2 & 1.1 & 0.39 & 2.2 \\
\hline CDK5 & 0.82 & 0.89 & 0.59 \\
\hline CDK9 & 0.32 & 1.1 & 0.6 \\
\hline CK1 & 0.61 & $>10$ & 0.088 \\
\hline CLK1 & 0.081 & 0.041 & 0.15 \\
\hline CLK2 & 0.18 & 0.047 & 0.52 \\
\hline CLK3 & 2.5 & 0.37 & 4.7 \\
\hline CLK4 & 0.1 & 0.048 & 0.042 \\
\hline DYRK1A & 0.12 & 0.093 & 0.47 \\
\hline DYRK1B & 0.09 & 0.14 & 0.41 \\
\hline DYRK2 & 0.12 & 0.082 & 0.6 \\
\hline DYRK3 & 1.3 & 2.1 & 1.7 \\
\hline GSK-3 & $>10$ & $>10$ & $>10$ \\
\hline LdDYRK1B & 0.42 & 1.6 & 0.88 \\
\hline LdDYRK3 & 0.42 & 3.3 & $>10$ \\
\hline LdDYRK4 & $>10$ & $>10$ & $>10$ \\
\hline TbCLK1 & $>10$ & $>10$ & $>10$ \\
\hline TcCLK1 & $>10$ & $>10$ & $>10$ \\
\hline CpCLK1 & $>10$ & 4.1 & 3.3 \\
\hline
\end{tabular}




\begin{tabular}{cccc}
\hline GlCLK & $>10$ & 2.1 & 2.8 \\
\hline $\boldsymbol{T g C L K}$ & $>10$ & 3.2 & 5.1 \\
\hline $\boldsymbol{L m D Y R K 2}$ & 2.2 & 2.2 & 5.2 \\
\hline $\boldsymbol{L m C L K}$ & $>10$ & $>10$ & $>10$ \\
\hline $\boldsymbol{P f C L K 1}$ & 0.22 & 0.21 & 1.4 \\
\hline
\end{tabular}

${ }^{\mathrm{a}} \mathrm{IC}_{50}$ values were estimated from dose-response curves and are shown in $\mu \mathrm{M} .>10$, less than $50 \%$ inhibition at $10 \mu \mathrm{M}$. 
Table 7. Kinase inhibition values $\mathrm{IC}_{50}{ }^{\mathrm{a}}$ in $\mu \mathrm{M}$ for pyrimidine derivatives.
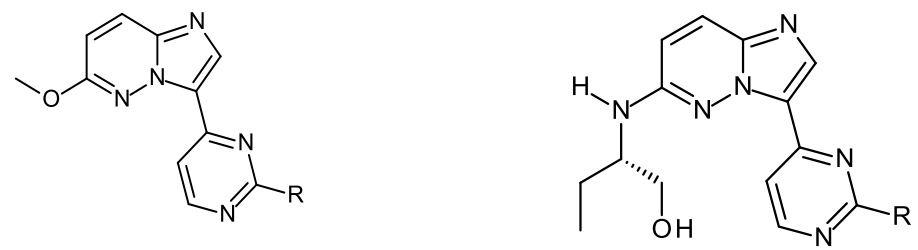

\begin{tabular}{|c|c|c|c|c|c|c|c|}
\hline $\mathbf{R}$ & $\mathrm{SMe}$ & SOMe & $\mathrm{NH}_{2}$ & $\mathrm{SMe}$ & SOMe & $\mathrm{SO}_{2} \mathrm{Me}$ & $\mathrm{NH}_{2}$ \\
\hline Compd & 21e & $21 f$ & $21 \mathbf{i}$ & 110 & $11 p$ & $11 q$ & $11 r$ \\
\hline CDK1 & $>10$ & $>10$ & 7.9 & 2.8 & $>10$ & $>10$ & 4.1 \\
\hline CDK2 & $>10$ & $>10$ & $>10$ & 4 & $>10$ & $>10$ & 5.1 \\
\hline CDK5 & $>10$ & $>10$ & $>10$ & 2.2 & $>10$ & $>10$ & 5.1 \\
\hline CDK9 & $>10$ & $>10$ & 5.6 & $>10$ & $>10$ & $>10$ & 2.2 \\
\hline CK1 & $>10$ & $>10$ & 1.6 & $>10$ & $>10$ & $>10$ & 1.2 \\
\hline CLK1 & 1.2 & 5.5 & 1.2 & 0.81 & 0.91 & 0.51 & 0.25 \\
\hline CLK2 & 1.8 & 8.2 & 1.3 & 0.69 & 1.6 & 0.81 & 1.1 \\
\hline CLK3 & $>10$ & $>10$ & $>10$ & $>10$ & $>10$ & 6.9 & 7.8 \\
\hline CLK4 & 0.38 & 1.8 & 0.31 & 0.31 & 0.29 & 0.2 & 0.13 \\
\hline DYRK1A & 0.93 & 5.1 & 1.5 & 1.7 & 4.4 & 1.8 & 3.2 \\
\hline DYRK1B & $>10$ & $>10$ & 3.8 & 1.1 & 3.5 & 1.9 & 2.2 \\
\hline DYRK2 & 1.2 & $>10$ & 1.4 & $>10$ & $>10$ & 10 & 0.4 \\
\hline DYRK3 & 7.9 & $>10$ & 2.3 & $>10$ & $>10$ & $>10$ & 0.32 \\
\hline GSK-3 & $>10$ & $>10$ & $>10$ & $>10$ & $>10$ & $>10$ & 4.1 \\
\hline LdDYRK1B & $>10$ & $>10$ & $>10$ & $>10$ & $>10$ & $>10$ & 6 \\
\hline$L d \mathrm{DYRK3}$ & $>10$ & $>10$ & $>10$ & $>10$ & $>10$ & $>10$ & $>10$ \\
\hline$L d$ DYRK4 & $>10$ & $>10$ & $>10$ & $>10$ & $>10$ & $>10$ & $>10$ \\
\hline
\end{tabular}




\begin{tabular}{cccccccc}
\hline TbCLK1 & $>10$ & $>10$ & $>10$ & $>10$ & $>10$ & $>10$ & $>10$ \\
\hline $\boldsymbol{T c C L K 1}$ & $>10$ & $>10$ & $>10$ & $>10$ & $>10$ & $>10$ & $>10$ \\
\hline CpCLK1 & $>10$ & $>10$ & $>10$ & $>10$ & $>10$ & $>10$ & 2.3 \\
\hline GlCLK & $>10$ & $>10$ & $>10$ & $>10$ & $>10$ & $>10$ & $>10$ \\
\hline $\boldsymbol{T g C L K}$ & $>10$ & $>10$ & $>10$ & $>10$ & $>10$ & $>10$ & $>10$ \\
\hline $\boldsymbol{L m D Y R K 2}$ & $>10$ & $>10$ & $>10$ & $>10$ & $>10$ & $>10$ & 3.7 \\
\hline LmCLK & $>10$ & $>10$ & $>10$ & $>10$ & $>10$ & $>10$ & $>10$ \\
\hline PfCLK1 & $>10$ & $>10$ & $>10$ & $>10$ & $>10$ & $>10$ & 3.1 \\
\hline
\end{tabular}

${ }^{\mathrm{a}} \mathrm{IC}_{50}$ values were estimated from dose-response curves and are shown in $\mu \mathrm{M}>10$, less than $50 \%$ inhibition at $10 \mu \mathrm{M}$. 
Table 8. Kinase inhibition values: $\mathrm{IC}_{50}{ }^{\mathrm{a}}$ in $\mu \mathrm{M}$ for aldehyde, acid and ester derivatives.
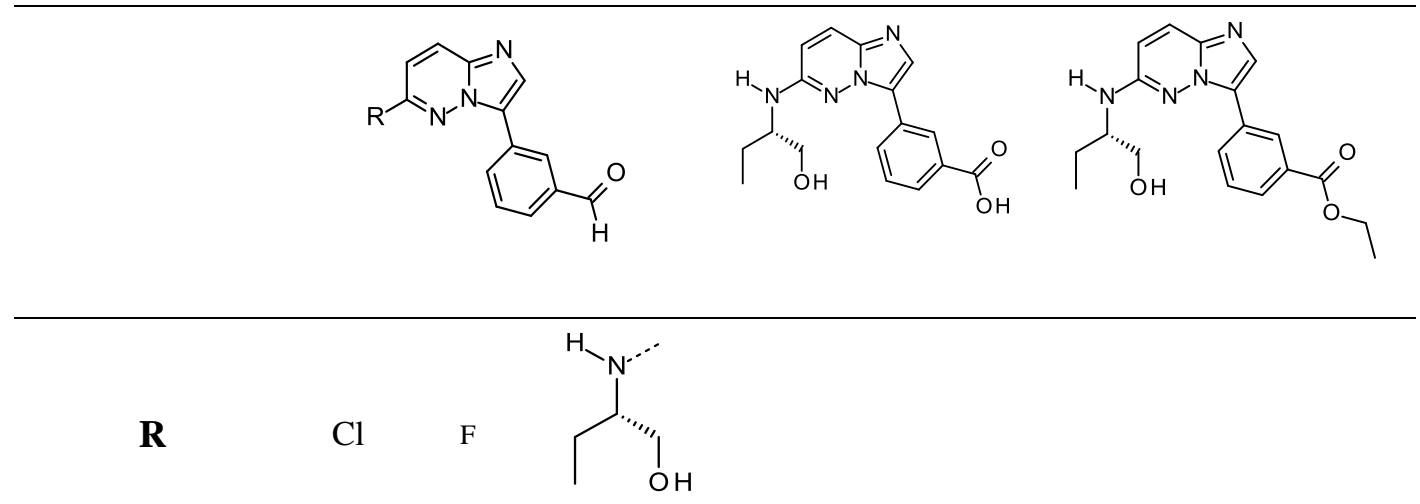

\begin{tabular}{|c|c|c|c|c|c|}
\hline Compd & $6 \mathrm{~m}$ & $5 b$ & 11u & $11 t$ & $11 \mathrm{~s}$ \\
\hline CDK1 & 7.9 & $>10$ & 0.76 & $>10$ & 0.36 \\
\hline CDK2 & $>10$ & $>10$ & $>10$ & $>10$ & 0.68 \\
\hline CDK5 & 0.82 & $>10$ & 0.48 & $>10$ & 1.1 \\
\hline CDK9 & 7.6 & $>10$ & 0.58 & $>10$ & 1.1 \\
\hline CK1 & 0.61 & 0.7 & 1.2 & $>10$ & 0.82 \\
\hline CLK1 & 0.31 & 1.8 & 0.041 & 0.69 & 0.057 \\
\hline CLK2 & 1.6 & 3.9 & 0.22 & 1.2 & 0.032 \\
\hline CLK3 & $>10$ & $>10$ & 2.9 & $>10$ & 0.82 \\
\hline CLK4 & 0.19 & 0.58 & 0.041 & 0.32 & 0.037 \\
\hline DYRK1A & 0.65 & 3.1 & 0.079 & 1.6 & 0.057 \\
\hline DYRK1B & 2.1 & 4.1 & 0.053 & 1.2 & 0.037 \\
\hline DYRK2 & 0.82 & 3 & 0.063 & 1.6 & 0.048 \\
\hline DYRK3 & 1.7 & $>10$ & 0.46 & 6.6 & 0.11 \\
\hline GSK-3 & $>10$ & $>10$ & 5.9 & $>10$ & $>10$ \\
\hline$L d D Y R K 1 B$ & 7.3 & $>10$ & 0.43 & 2.1 & 0.13 \\
\hline LdDYRK3 & $>10$ & $>10$ & 4.8 & $>10$ & 1.3 \\
\hline LdDYRK4 & $>10$ & $>10$ & $>10$ & $>10$ & $>10$ \\
\hline TbCLK1 & $>10$ & $>10$ & $>10$ & $>10$ & $>10$ \\
\hline
\end{tabular}




\begin{tabular}{cccccc}
\hline $\boldsymbol{T c C L K 1}$ & $>10$ & $>10$ & $>10$ & $>10$ & 0.8 \\
\hline $\boldsymbol{C p C L K 1}$ & $>10$ & $>10$ & 1 & $>10$ & 0.75 \\
\hline $\boldsymbol{G l C L K}$ & $>10$ & $>10$ & 1.6 & 1.9 & 0.98 \\
\hline $\boldsymbol{T g C L K}$ & $>10$ & $>10$ & 2.8 & 5.3 & $>10$ \\
\hline $\boldsymbol{L m D Y R K 2}$ & $>10$ & $>10$ & 1.3 & $>10$ & 0.19 \\
\hline $\boldsymbol{L m C L K}$ & $>10$ & $>10$ & $>10$ & 2.1 &
\end{tabular}

${ }^{\mathrm{a}} \mathrm{IC}_{50}$ values were estimated from dose-response curves and are shown in $\mu \mathrm{M} .>10$, less than $50 \%$ inhibition at $10 \mu \mathrm{M}$. 
Table 9. Kinase inhibition values: ${ }^{\mathrm{a}} \mathrm{IC}_{50}$ in $\mu \mathrm{M}$ for imine and oxime derivatives.

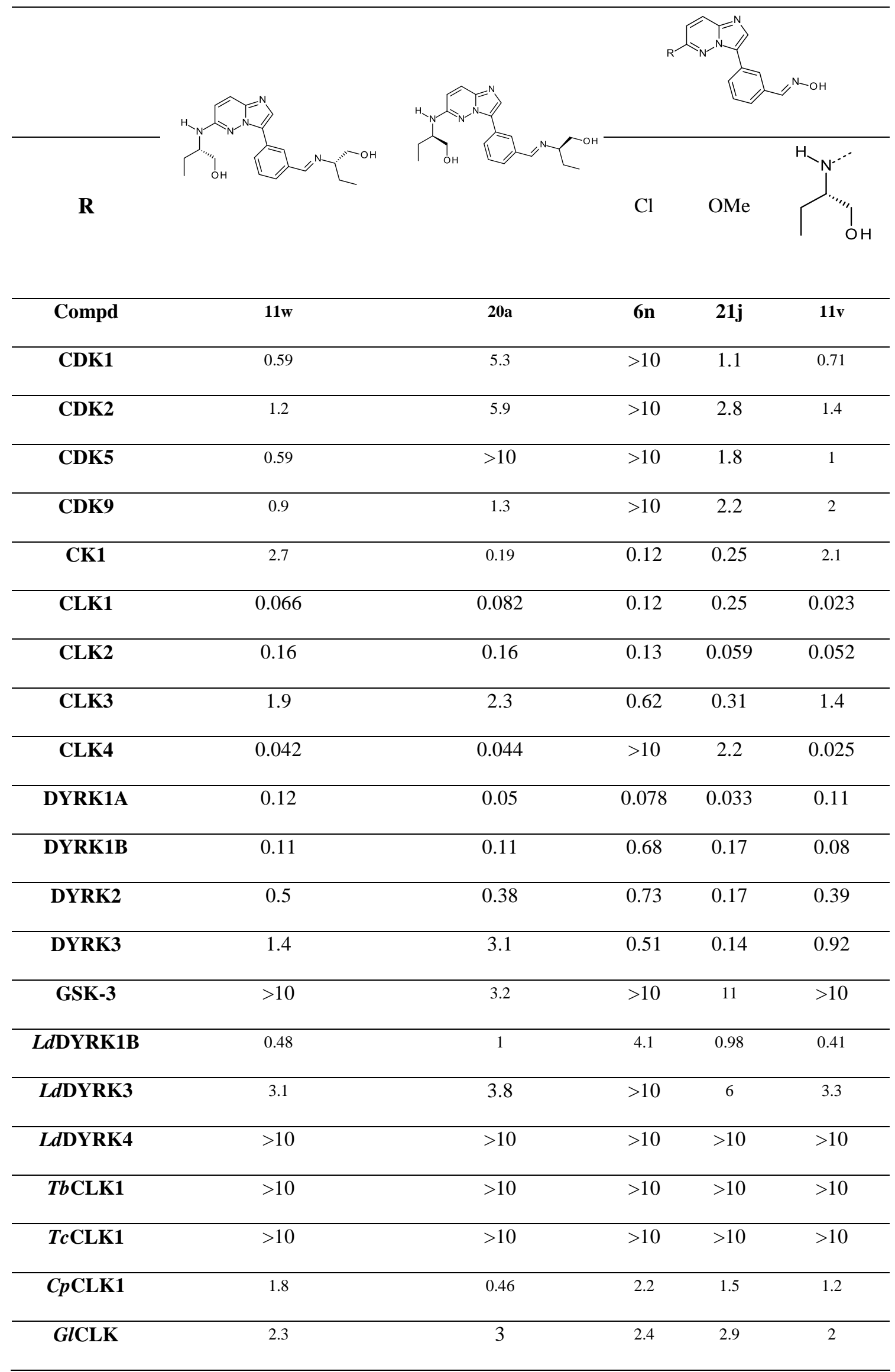




\begin{tabular}{cccccc}
\hline $\boldsymbol{T g C L K}$ & 1.4 & 1.7 & $>10$ & 6.3 & 0.73 \\
\hline $\boldsymbol{L m D Y R K 2}$ & 1.7 & 0.81 & 7.8 & 4.2 & 0.98 \\
\hline $\boldsymbol{L m C L K}$ & $>10$ & $>10$ & $>10$ & $>10$ & $>10$ \\
\hline $\boldsymbol{P f C L K 1 ~}$ & 0.37 & 0.032 & 0.83 & 1.1 & 0.31 \\
\hline
\end{tabular}

${ }^{\mathrm{a}} \mathrm{IC}_{50}$ values were estimated from dose-response curves and are shown in $\mu \mathrm{M}$. $>10$, less than $50 \%$ inhibition at $10 \mu \mathrm{M}$. 

Table 10. Kinase inhibition values: $\mathrm{IC}_{50}{ }^{\mathrm{a}}$ in $\mu \mathrm{M}$ for amide derivatives.
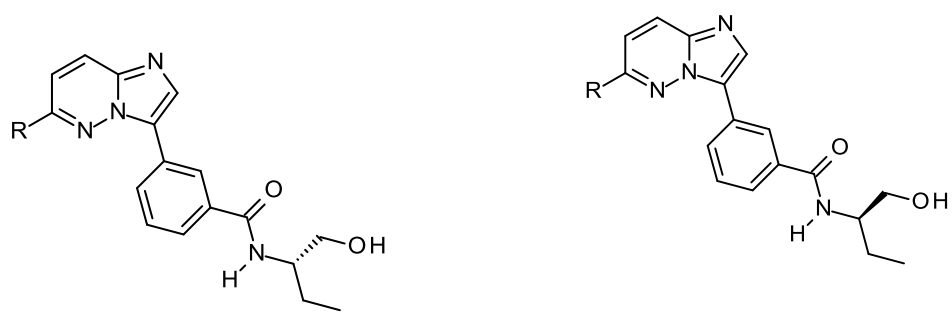

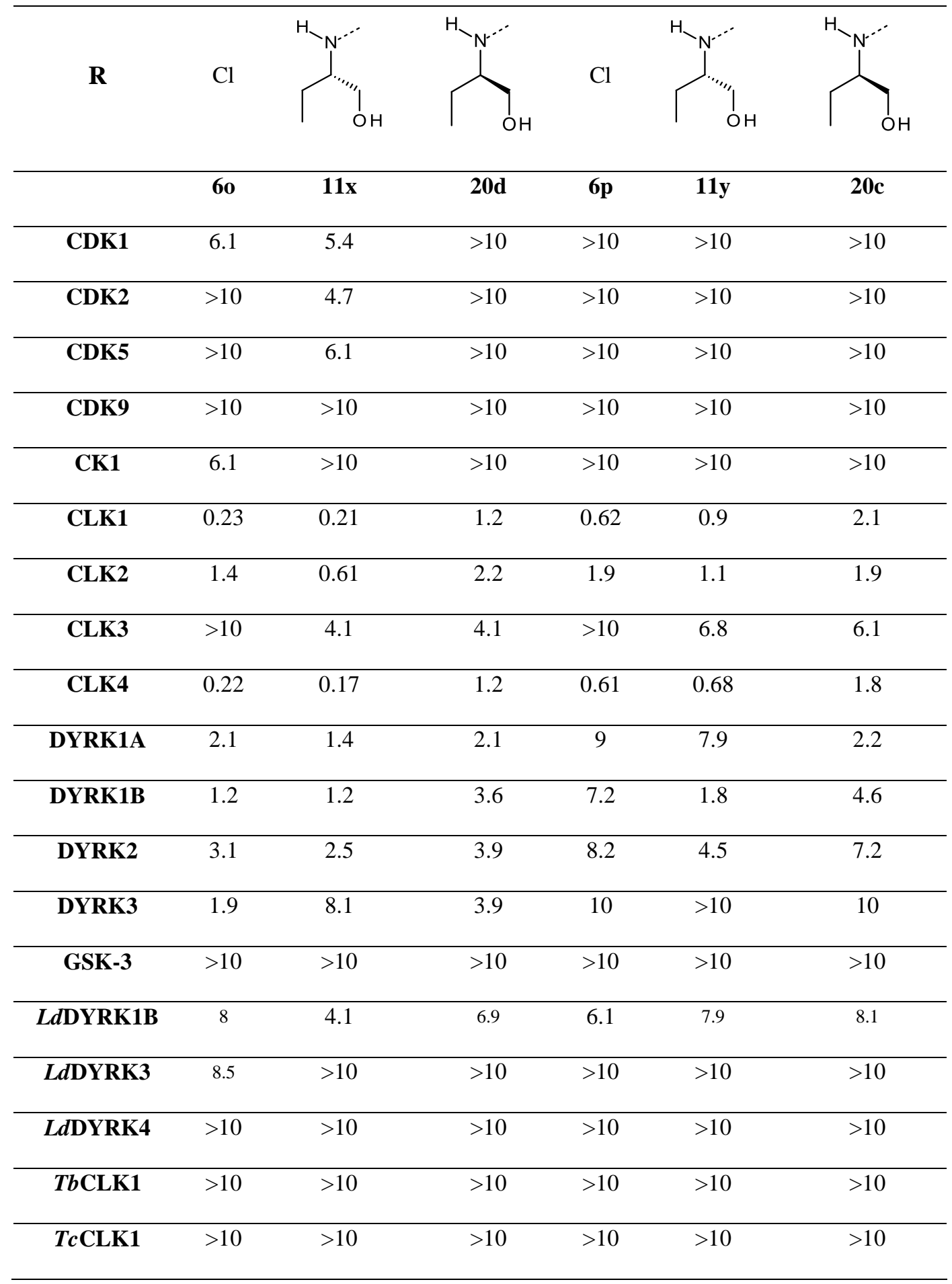




\begin{tabular}{ccccccc}
\hline $\boldsymbol{C p C L K 1}$ & $>10$ & 8.7 & 9.3 & $>10$ & $>10$ & $>10$ \\
\hline $\boldsymbol{G l C L K}$ & $>10$ & $>10$ & $>10$ & $>10$ & $>10$ & $>10$ \\
\hline $\boldsymbol{T g C L K}$ & $>10$ & $>10$ & $>10$ & $>10$ & $>10$ & $>10$ \\
\hline $\boldsymbol{L m D Y R K 2}$ & $>10$ & $>10$ & $>10$ & $>10$ & $>10$ & $>10$ \\
\hline $\boldsymbol{L m C L K}$ & $>10$ & $>10$ & $>10$ & $>10$ & $>10$ & 0.81 \\
\hline $\boldsymbol{P f C L K 1}$ & 3.9 & 4.9 & 0.59 & 6.9 & 4.2 & \\
\hline
\end{tabular}

${ }^{\mathrm{a}} \mathrm{IC}_{50}$ values were estimated from dose-response curves and are shown in $\mu \mathrm{M}$. > 10, less than $50 \%$ inhibition at $10 \mu \mathrm{M}$. 
Table 11. Anti-leishmanial activity on promastigotes. A miniaturized dye reduction assay (resazurin-based assay) was used to estimate the leishmanicidal activity of each compound (PMID:11227767). Three compound concentrations $(20,4$ and $0.8 \mu \mathrm{M})$ were tested in quadruplicates for 3 days on promastigotes. Following subtraction of the mean background fluorescence value from the medium controls data were expressed as Percent of Inhibition (PI) as compared to untreated parasite culture wells. The mean+/- standard deviation is shown for every tested compound.

\begin{tabular}{|c|c|c|c|c|c|c|}
\hline \multirow[t]{2}{*}{ Cmpd } & \multicolumn{2}{|c|}{$20 \mu \mathrm{M}$} & \multicolumn{2}{|c|}{$4 \mu \mathrm{M}$} & \multicolumn{2}{|c|}{$0.8 \mu \mathrm{M}$} \\
\hline & Mean & StDev & Mean & StDev & Mean & StDev \\
\hline $10 a$ & 22,4 & 2,8 & $-1,6$ & 2,3 & $-0,7$ & 2,0 \\
\hline $11 \mathrm{a}$ & $-13,1$ & 7,8 & 3,1 & 2,7 & $-5,9$ & 2,9 \\
\hline $11 \mathrm{~b}$ & 74,3 & 3,1 & 28,3 & 2,2 & $-1,8$ & 2,3 \\
\hline 11c & 100,0 & 0,1 & $-4,7$ & 0,9 & 5,4 & 11,2 \\
\hline 11d & 1,8 & 2,8 & 3,7 & 3,5 & $-7,0$ & 3,6 \\
\hline $11 \mathrm{e}$ & 59,5 & 13,6 & $-4,8$ & 8,0 & $-3,7$ & 2,8 \\
\hline $11 f$ & $-16,3$ & 5,8 & $-12,1$ & 1,1 & $-3,5$ & 1,5 \\
\hline $11 \mathrm{~g}$ & 93,3 & 0,9 & $-8,3$ & 5,9 & 4,6 & 4,7 \\
\hline $11 \mathrm{~h}$ & $-2,5$ & 12,9 & $-23,5$ & 2,0 & $-2,3$ & 3,7 \\
\hline $11 \mathrm{i}$ & 12,0 & 6,4 & 6,8 & 2,0 & $-3,3$ & 1,9 \\
\hline $11 \mathrm{j}$ & $-37,0$ & 3,4 & 5,0 & 2,4 & $-0,8$ & 7,3 \\
\hline $11 \mathrm{k}$ & 2,9 & 7,3 & 20,8 & 1,4 & $-8,5$ & 1,2 \\
\hline 111 & 86,5 & 3,7 & $-25,6$ & 5,3 & $-7,6$ & 1,1 \\
\hline $11 \mathrm{~m}$ & $-9,6$ & 18,4 & 18,3 & 1,3 & 0,2 & 9,6 \\
\hline $11 n$ & 21,5 & 4,7 & 35,1 & 2,6 & 3,5 & 1,8 \\
\hline 110 & 39,6 & 7,5 & 24,9 & 1,5 & $-2,8$ & 1,6 \\
\hline 11p & 15,2 & 5,2 & 1,4 & 3,8 & $-5,5$ & 1,1 \\
\hline $11 q$ & 11,5 & 6,6 & 1,2 & 0,6 & $-4,9$ & 1,3 \\
\hline $11 r$ & 20,8 & 7,9 & 34,5 & 2,1 & 2,1 & 2,7 \\
\hline $11 \mathrm{~s}$ & 84,7 & 3,8 & $-13,1$ & 3,7 & $-9,5$ & 2,3 \\
\hline $11 t$ & 13,5 & 9,1 & 16,1 & 3,0 & $-8,1$ & 2,5 \\
\hline $11 u$ & $-33,2$ & 4,1 & $-4,3$ & 4,0 & 0,0 & 7,3 \\
\hline $11 v$ & 12,4 & 18,1 & 31,9 & 5,2 & $-5,1$ & 1,8 \\
\hline $11 w$ & $-17,0$ & 23,0 & 26,6 & 3,8 & $-7,7$ & 4,0 \\
\hline $11 x$ & 9,4 & 6,5 & 3,2 & 3,1 & $-1,8$ & 2,9 \\
\hline $11 y$ & 98,8 & 0,1 & $-36,2$ & 2,4 & $-10,7$ & 1,3 \\
\hline 12 & $-23,6$ & 8,8 & 16,5 & 4,2 & $-2,5$ & 2,6 \\
\hline 13 & 3,4 & 2,9 & $-0,4$ & 5,2 & 0,7 & 1,2 \\
\hline 14 & 16,8 & 5,3 & 21,3 & 2,4 & 3,1 & 4,2 \\
\hline 15 & $-11,9$ & 0,9 & $-1,9$ & 3,9 & 0,0 & 4,9 \\
\hline 16 & 40,7 & 6,9 & 12,9 & 5,2 & $-5,6$ & 5,3 \\
\hline 17 & 99,8 & 0,1 & 16,5 & 16,4 & $-4,3$ & 5,3 \\
\hline 18 & 1,6 & 1,7 & 26,2 & 3,8 & $-1,3$ & 8,1 \\
\hline 19 & 17,8 & 3,5 & 32,5 & 5,1 & $-5,2$ & 5,2 \\
\hline $20 \mathrm{a}$ & $-23,2$ & 4,3 & 12,3 & 9,8 & $-1,3$ & 2,8 \\
\hline 20c & 25,7 & 2,8 & 10,8 & 3,2 & $-9,5$ & 5,1 \\
\hline
\end{tabular}




\begin{tabular}{cccccccc}
\cline { 4 - 7 } 20d & 91,9 & & 0,6 & 19,8 & 5,2 & $-12,3$ & 5,3 \\
\hline 21a & $-11,6$ & 5,5 & 26,5 & 1,1 & 4,7 & 4,4 \\
\hline 21b & $-9,0$ & 2,8 & 12,8 & 1,9 & 2,9 & 5,1 \\
\hline 21c & 22,4 & 6,3 & 3,7 & 3,2 & 0,0 & 2,4 \\
\hline 21d & 37,2 & 6,8 & 16,5 & 6,1 & 0,6 & 4,6 \\
\hline 21e & 0,7 & 3,4 & 34,6 & 3,1 & $-5,8$ & 2,2 \\
\hline 21f & 13,7 & 5,8 & 16,7 & 0,9 & $-3,2$ & 2,3 \\
\hline 21i & 4,2 & 8,7 & 6,2 & 8,8 & $-3,5$ & 2,5 \\
\hline 21j & 8,6 & 6,2 & 9,6 & 8,0 & 6,0 & 4,5 \\
\hline 22b & $-24,2$ & 4,2 & 26,9 & 3,9 & 2,7 & 7,8 \\
\hline 22c & $-15,0$ & 5,7 & $-2,1$ & 1,5 & 0,7 & 4,0 \\
\hline
\end{tabular}

\begin{tabular}{ccccccc} 
Roscovitine & $-20,3$ & 2,5 & $-3,8$ & 4,3 & $-8,8$ & 3,9 \\
\hline MRT2-08 & 19,2 & 4,3 & 0,7 & 6,3 & $-8,7$ & 1,0 \\
\hline
\end{tabular}


Figure 1.The imidazo[1,2-b]pyridazine scaffold: selected kinase inhibitors.

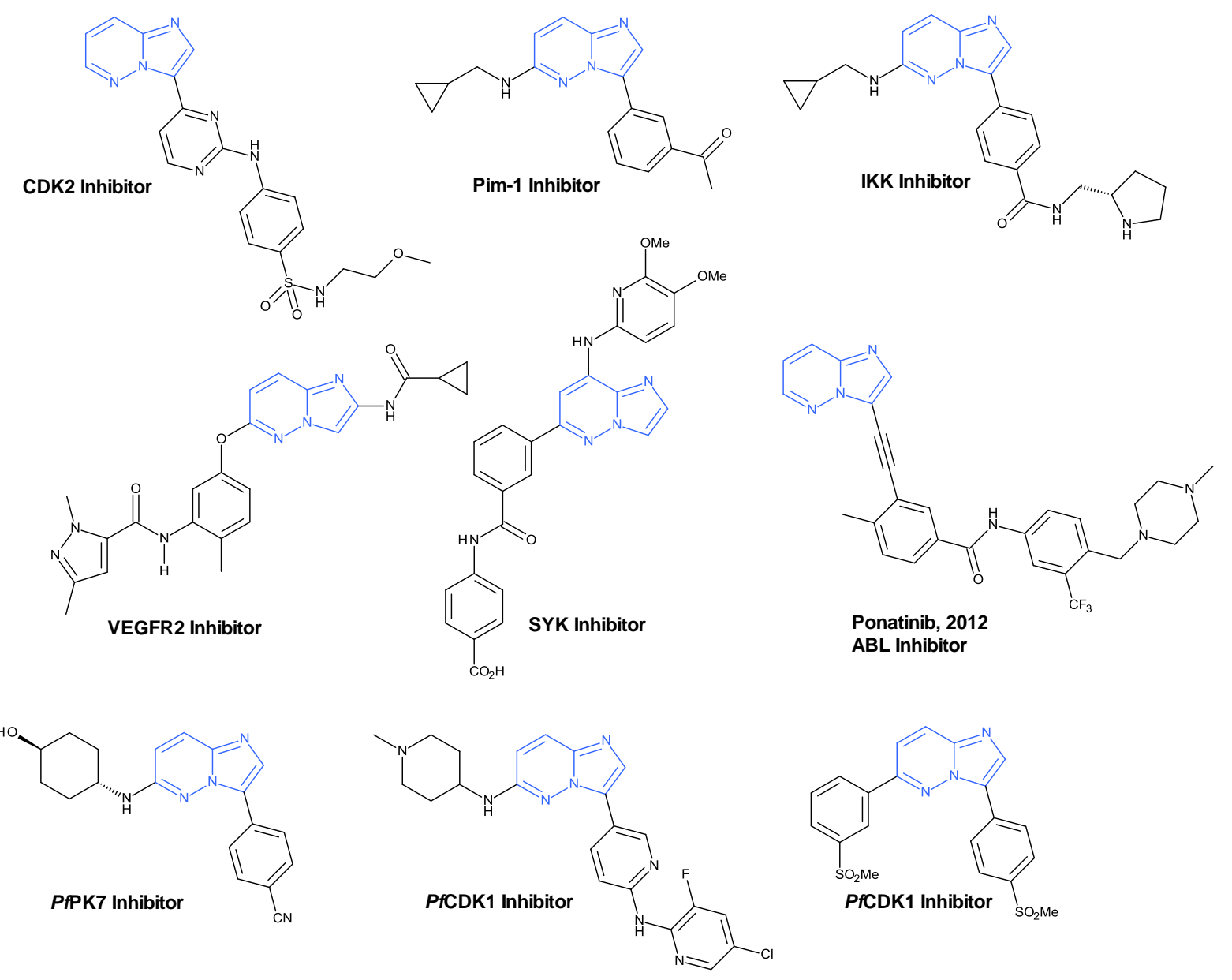


Scheme 1. General synthetic strategy, C3, C6-disubstituted imidazo[1,2-b]pyridazines. Reagent and conditions: (a) i $n \mathrm{BuOH}, 18 \mathrm{~h}$, reflux, ii $\mathrm{H}_{2} \mathrm{O}, \mathrm{NaOH}$; (b) $\mathrm{NBS}, \mathrm{CHCl}_{3}, 8 \mathrm{~h}, 2{ }^{\circ} \mathrm{C}$; (c) boronic acid or ester, $\mathrm{Pd}\left[\mathrm{P}\left(\mathrm{C}_{6} \mathrm{H}_{5}\right)_{3}\right]_{4}, \mathrm{Na}_{2} \mathrm{CO}_{3}(2 \mathrm{M}), 1$,4-dioxane, $100{ }^{\circ} \mathrm{C}$; (d) 2-amino-1-butanol, 160-180 ${ }^{\circ} \mathrm{C}$; (e) $\mathrm{Pd}(\mathrm{OAc})_{2}$, xantphos, $t$-BuOK, $\mathrm{H}_{2} \mathrm{O}, 1$,4-dioxane, $100{ }^{\circ} \mathrm{C}$, 48h; (f) $\mathrm{NaOMe}, \mathrm{MeOH}, 48 \mathrm{~h}$, reflux; (g)

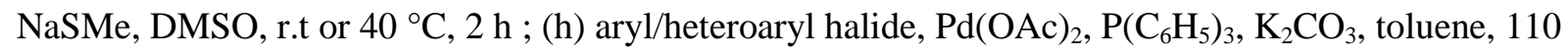
${ }^{\circ} \mathrm{C}$; (i) KF, DMSO/toluene, $170{ }^{\circ} \mathrm{C}, 6 \mathrm{~h}$.

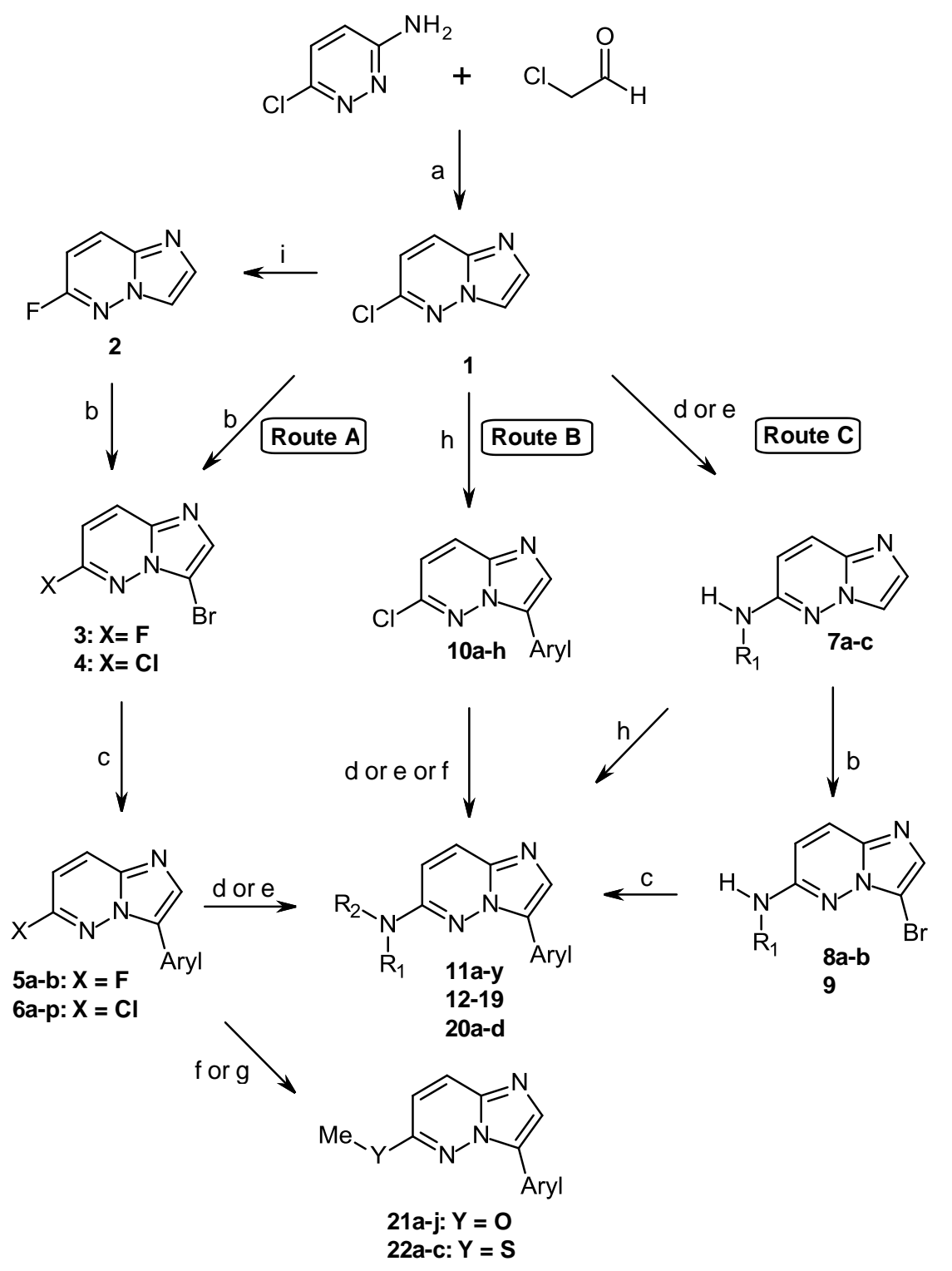


Scheme 2. Procedure for the Synthesis of compound 14. Reagent and conditions : (a) $\mathrm{Pd}(\mathrm{OAc})_{2}$, xantphos, $t$-BuOK, $\mathrm{H}_{2} \mathrm{O}, 1$,4-dioxane, $100{ }^{\circ} \mathrm{C}, 24 \mathrm{~h}, 27 \%$; (b) $\mathrm{NBS}, \mathrm{CHCl}_{3}, 20{ }^{\circ} \mathrm{C}, 4 \mathrm{~h}, 100 \%$; (c) 3chlorophenylboronic pinacol ester, $\mathrm{Pd}\left[\mathrm{P}(\mathrm{Ph})_{3}\right]_{4}, \mathrm{Na}_{2} \mathrm{CO}_{3}(2 \mathrm{M}), 1,4$-dioxane, $100{ }^{\circ} \mathrm{C}, 6 \mathrm{~h}, 5 \%$

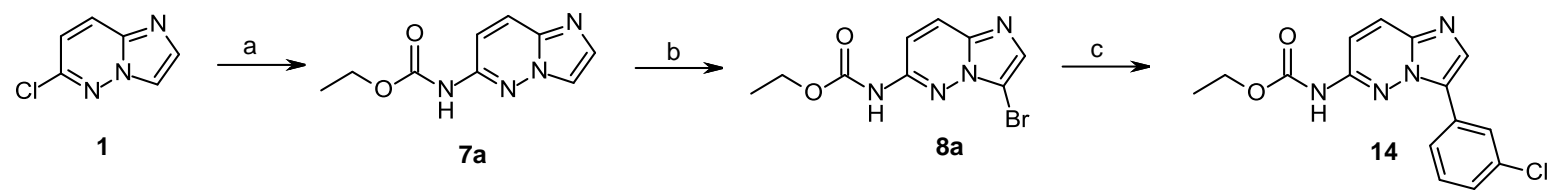


Scheme

Scheme 3. Procedure for the synthesis of compound 15. Reagents and conditions: (a) $\operatorname{Pd}(\mathrm{OAc})_{2}$, xantphos, $t$-BuOK, $\mathrm{H}_{2} \mathrm{O}, 1$,4-dioxane, $100{ }^{\circ} \mathrm{C}, 24 \mathrm{~h}, 30 \%$.
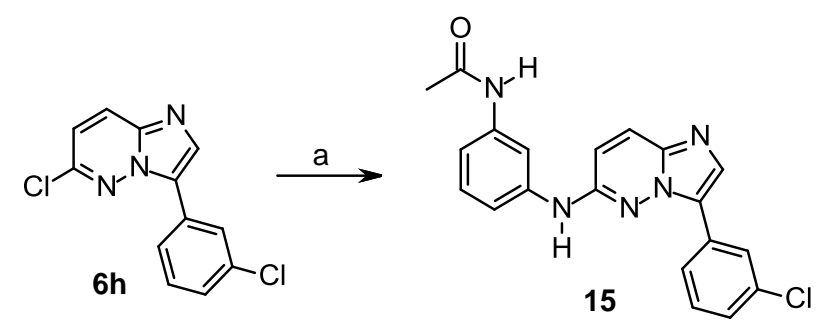
Scheme 4. Procedure for the synthesis of acetamides 111 and 18. Reagents and conditions: (a) acetic anhydride, DMAP, Et 3 N, DCM, $20{ }^{\circ} \mathrm{C}, 2$ h, 79\%; (b) (S)-2-amino-1-butanol, $160{ }^{\circ} \mathrm{C}, 7$ h, 7\%; (b') (S)2-amino-1-butanol, $180{ }^{\circ} \mathrm{C}, 7$ h, 26\%; (a') acetic anhydride, DMAP, Et 3 N, DCM, r.t, 2 h, $57 \%$.

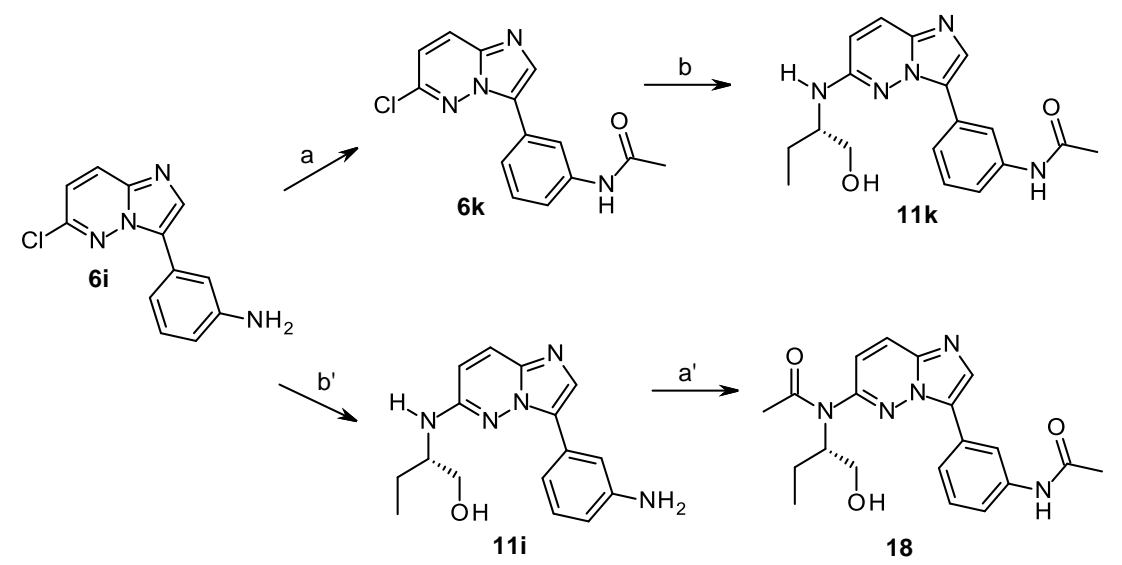


Scheme 5. Procedure for the synthesis of pyrimidine derivatives. Reagents and conditions : (a) TMSBr, $\mathrm{CH}_{3} \mathrm{CN}, 40{ }^{\circ} \mathrm{C}, 27 \mathrm{~h}, 98 \%$; (b) 6-chloro-imidazo[1,2-b]pyridazine, $\mathrm{Pd}(\mathrm{OAc})_{2}, \mathrm{PPh}_{3}, \mathrm{~K}_{2} \mathrm{CO}_{3}$, toluene, 2 days, $110{ }^{\circ} \mathrm{C}, 38 \%$; (c) mCPBA, DCM, r.t; (d) MeONa, MeOH, 6 h, $80{ }^{\circ} \mathrm{C}$; (e) (S)-2-amino1-butanol, $170{ }^{\circ} \mathrm{C}, 4 \mathrm{~h}$.<smiles>CSc1nccc(Cl)n1</smiles><smiles>CCCSc1nccc(Br)n1</smiles>

23<smiles>CSc1nccc(-c2cnc3ccc(Cl)nn23)n1</smiles><smiles>[R]c1ccc2ncc(-c3ccnc(SC)n3)n2n1</smiles>

$c$<smiles>[R]c1ccc2ncc(-c3ccnc(S(C)(=O)=O)n3)n2n1</smiles>

$11 q: R=(S)-2-a m i n o-1-$ butanol<smiles>[R]c1ccc2ncc(-c3ccnc(S(C)=O)n3)n2n1</smiles>

$11 p: R=(S)-2$-amino-1-butanol 21f : $\mathrm{R}=\mathrm{OMe}$<smiles>[R]c1ccc2ncc(-c3ccnc(S(C)(=O)=O)n3)n2n1</smiles>

21g: $\mathrm{R}=\mathrm{OMe}$ 
Scheme 6. Procedure for the synthesis of pyrimidine derivatives. Reagents and conditions: (g) 1,4dioxane, 8 h, reflux; (h) TFA, DCM, $20{ }^{\circ} \mathrm{C}$; (i) (S)-2-amino-1-butanol, $6 \mathrm{~h}, 160{ }^{\circ} \mathrm{C}$..<smiles>[R]c1ccc2ncc(-c3ccnc(S(C)(=O)=O)n3)n2n1</smiles><smiles>COc1ccc(CN)c(OC)c1</smiles><smiles>[R]c1ccc2ncc(-c3ccnc(NCc4ccc(OC)cc4OC)n3)n2n1</smiles>

21h: $\mathrm{R}=\mathrm{OMe}$

10e: $\mathrm{R}=\mathrm{Cl}$<smiles>[R]c1ccc2ncc(-c3ccnc(NN)n3)n2n1</smiles>

21i : $\mathrm{R}=\mathrm{OMe}$

10f: $\mathrm{R}=\mathrm{Cl}$<smiles>CC[C@H](CO)Nc1ccc2ncc(-c3ccnc(N)n3)n2n1</smiles>

11r: From $\mathrm{R}=\mathrm{Cl}$ 
Scheme 7. Procedure for the synthesis of imines. Reagents and conditions : (a) KF, DMSO/Toluene, 8h, $180^{\circ} \mathrm{C}, 46 \%$; (b) $\mathrm{NBS}, \mathrm{CHCl}_{3}, 6$ h, r.t, 93\%; (c) 3-formylphenylboronic acid, $\mathrm{Pd}\left[\mathrm{P}\left(\mathrm{C}_{6} \mathrm{H}_{5}\right)_{3}\right]_{4}$, $\mathrm{Na}_{2} \mathrm{CO}_{3}(2 \mathrm{M}), 1,4$-dioxane, $6 \mathrm{~h}, 100{ }^{\circ} \mathrm{C}, 63 \%$; (d) (R)-2-amino-1-butanol, $135^{\circ} \mathrm{C}, 2 \mathrm{~h}$.<smiles>Clc1ccc2nccn2n1</smiles>

1<smiles>C[13CH2][13CH](C)c1ccc2ncc(-c3cccc(C=O)c3)n2n1</smiles><smiles>Fc1ccc2nccn2n1</smiles>

2<smiles>CC[C@H](CO)Nc1ccc2ncc(-c3cccc(C=O)c3)n2n1</smiles>

20b<smiles>Fc1ccc2ncc(Br)n2n1</smiles><smiles>CC[C@H](CO)Nc1ccc2ncc(-c3cccc(C=N)c3)n2n1</smiles>

20a 
Scheme

Scheme 8. Procedure for the synthesis of acid and ethyl ester derivative. Reagents and conditions : (a) (S)-2-amino-1-butanol, $8 \mathrm{~h}, 180^{\circ} \mathrm{C}, 69 \%$; (c) Ethyl 3-bromobenzoate, $\mathrm{Pd}(\mathrm{OAc})_{2}, \mathrm{P}\left(\mathrm{C}_{6} \mathrm{H}_{5}\right)_{3}, \mathrm{~K}_{2} \mathrm{CO}_{3}$, toluene, $8 \mathrm{~h}, 110{ }^{\circ} \mathrm{C}, 10 \%$; (c) i: $\mathrm{NaOH}(1 \mathrm{~N}), \mathrm{THF} / \mathrm{EtOH}$, ii: $\mathrm{HCl}(1 \mathrm{~N}), \mathrm{H}_{2} \mathrm{O}, 28 \%$; (d) 3-formylphenylboronic acid, $\mathrm{Pd}\left[\mathrm{P}\left(\mathrm{C}_{6} \mathrm{H}_{5}\right)_{3}\right]_{4}, \mathrm{Na}_{2} \mathrm{CO}_{3}(2 \mathrm{M}), 1,4-$ dioxane, $12 \mathrm{~h}, 100{ }^{\circ} \mathrm{C}$. (e) (S)-2-amino-1-butanol, 3 days 20 to $60{ }^{\circ} \mathrm{C}$.

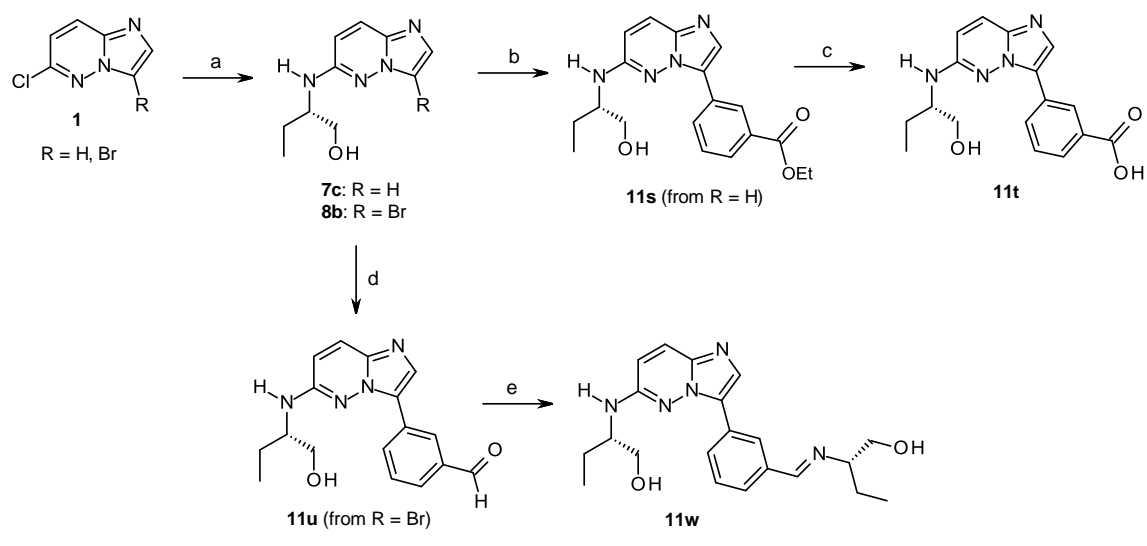


Scheme 9: Procedure of the synthesis of amide. Reagents and conditions: (a) (S or R)-2amino-1-butanol, DCC/HOBt, Et 3 N, THF/DCM, $20^{\circ} \mathrm{C}, 24 \mathrm{~h}$; (b) (S or R)-2-amino-1-butanol, $180^{\circ} \mathrm{C}, 12 \mathrm{~h}$.<smiles>O=C(O)c1cccc(-c2cnc3ccc(Cl)nn23)c1</smiles><smiles>CCC(N)CO</smiles><smiles>[13CH3]</smiles><smiles>CC[C@H](CO)NC(=O)c1cccc(-c2cnc3ccc(Cl)nn23)c1</smiles>

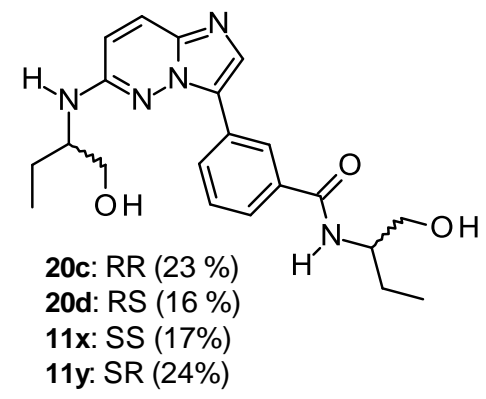



Supplementary Material - For Publication Online
Click here to download Supplementary Material - I Supplementary Material - For Publication Online
Click here to download Supplementary Material - For Publication Online: Supplementary material_Imidazo[1,2-b]Pyridazines_ 


\section{Supplementary Material - For Publication Online}

Click here to download Supplementary Material - For Publication Online: Supplementary material_ Imidazo[1,2-b]Pyridazines_2.| 